\title{
Coralligenous assemblages along their geographical distribution: Testing of concepts and implications for management
}

\author{
Melih Ertan Çinar $^{1}$ | Jean-Pierre Féral ${ }^{2} \quad$ | Christos Arvanitidis $^{3}$ | \\ Romain David $^{2}$ | Ergün Taşkin ${ }^{4}$ | Maria Sini ${ }^{5} \quad$ | Thanos Dailianis ${ }^{3}$ | \\ Alper Doğan $^{1} \quad$ | Vasilis Gerovasileiou ${ }^{3} \quad$ | Alper Evcen ${ }^{1} \quad$ | Anne Chenuil ${ }^{2}$ | \\ Ertan Dağli $^{1} \quad$ | Veysel Aysel ${ }^{6} \quad$ | Yannis Issaris $^{7}$ | Kerem Bakir ${ }^{1}$ । \\ Melina Nalmpantı $^{8,9} \quad$ | Stephane Sartoretto ${ }^{2} \quad$ | Maria Salomidi $^{7}$ | \\ Anastasia Sapouna $^{5} \quad$ | Sermin Açik ${ }^{10} \quad$ | Charalampos Dimitriadis $^{11}$ | \\ Drosos Koutsoubas $^{5,11}$ | Tuncer Katağan ${ }^{1} \quad$ | Bilal Öztürk ${ }^{1}$ | \\ Ferah Koçak $^{10}$ ｜ Deniz Erdogan-Dereli ${ }^{1} \quad$ Senem Önen ${ }^{1} \quad$ Özge Özgen ${ }^{10}$ | \\ Neslihan Türkçü ${ }^{1} \quad$ Fevzi Kirkim ${ }^{1} \quad$ | Mesut Önen ${ }^{1}$ \\ ${ }^{1}$ Faculty of Fisheries, Ege University, Bornova, İzmir, Turkey \\ ${ }^{2} \mathrm{AMU} / \mathrm{CNRS} / \mathrm{IRD} / \mathrm{UA}$, Mediterranean Institute of Biodiversity and Marine and Terrestrial Ecology (IMBE), Station Marine d'Endoume, Marseille, France \\ ${ }^{3}$ Institute of Marine Biology, Biotechnology and Aquaculture, Hellenic Centre for Marine Research (HCMR), Heraklion, Crete, Greece \\ ${ }^{4}$ Faculty of Arts and Sciences, Manisa Celal Bayar University, Manisa, Turkey \\ ${ }^{5}$ Faculty of Environment, University of the Aegean, Mytilene, Lesvos, Greece \\ ${ }^{6}$ Faculty of Sciences, Dokuz Eylül University, Buca, İzmir, Turkey \\ ${ }^{7}$ Institute of Oceanography, Hellenic Centre for Marine Research (HCMR), Anavyssos, Attiki, Greece \\ ${ }^{8}$ Functional Ecology, Biosciences, Alfred-Wegener-Institute, Am Handelshafen 12, 27570 Bremerhaven, Germany \\ ${ }^{9}$ University of Bremen, Bibliothekstraße 1, 28359 Bremen, Germany \\ ${ }^{10}$ Institute of Marine Sciences and Technology, Dokuz Eylül University, İzmir, Turkey \\ ${ }^{11}$ National Marine Park of Zakynthos, Zakynthos, Greece \\ Correspondence \\ Melih Ertan Çinar, Faculty of Fisheries, Ege University, Bornova, Izmir, Turkey. Email: melih.cinar@ege.edu.tr
}

\section{Abstract}

1. The coralligenous habitat was studied at the large Mediterranean scale, by applying a standardized, nondestructive photo-sampling protocol, developed in the framework of the CIGESMED project.

2. The results provided evidence to support the following statements: (a) the assem-blage pattern is not homogeneously distributed across the four Mediterranean ecoregions studied (biotic gradients hypothesis); and (b) the assemblage pattern does not change significantly when the information is aggregated to higher taxonomic levels (taxonomic sufficiency hypothesis).

3. Surrogate taxonomic categories higher than species, such as genus and family, can be used to reveal the multivariate pattern of the coralligenous assemblages. 
4. Although preliminary at the pan-Mediterranean scale, these outcomes set the scene for future comparisons as more data sets become available but also for comparisons between taxonomic and functional patterns.

\section{KEYWOR DS}

algae, benthos, biodiversity, biogeography, circalittoral, coastal, habitat management, invertebrates, reef

\section{1 | INTRODUCTION}

Coralligenous habitat is a calcareous formation, primarily composed by long-lived encrusting red algae and, secondarily, by sessile invertebrates growing on submerged reefs under dim light conditions; it is considered as an endemic, protected Mediterranean habitat (Ballesteros, 2006). Although prevailing between 20 and $120 \mathrm{~m}$ depth, sometimes large, continuous formations of this habitat occurs in shallow waters under high turbidity (Casellato \& Stefanon, 2008). Along with similar formations (bio-concretions), it has contributed to the formation of benthic biogenic structures over geological time, resulting in geomorphological changes of the benthic environment (Bracchi, Basso, Marchese, Corselli, \& Savini, 2017). The coralligenous habitat provides a number of microhabitats, in the form of numerous crevices and cavities generated by the overlapping growth of algal thalli and by the bioeroding action of some sponges and bivalves (Ballesteros, 2006). This unique habitat, together with seagrass meadows and marine caves, is acknowledged as a hot-spot of marine biodiversity in the Mediterranean (Boudouresque et al., 2016; Gerovasileiou \& Voultsiadou, 2012; Martin \& Gattuso, 2009). Under the Habitats Directive (92/43/EU), coralligenous assemblages may be collectively addressed under the generic habitat type Reefs (1170), which, however, lacks priority conservation status. Recognizing its unique ecological importance, as well as the main threats that it has faced during recent decades, coralligenous habitat has been put forward to be assigned as a distinct habitat category and with a priority conservation status by UNEP (1998). More specifically, the mass mortality events frequently experienced in the Mediterranean Sea (Cerrano et al., 2000; Coma et al., 2009) related to global climate change have encouraged decision makers to take some necessary precautions for the protection of this unique habitat. Coralligenous habitat has also been declared as a protected habitat under the Mediterranean Fisheries Regulation (1967/2006), particularly because of its sensitivity to mechanical impact from fisheries, as well as its importance in hosting various life cycle stages of numerous commercial fish and invertebrates. However, so far, the Mediterranean countries have not taken any action on the protection and monitoring of this particular habitat, most probably because: (a) there is only detailed mapping in a few places in the entire basin; and (b) a comprehensive study at the basin scale has not been in place. Apart from its ecological and economic importance, coralligenous habitat hosts many species that have been granted a protected status by numerous international treaties. For example, almost all endangered and threatened species of Porifera, Cnidaria, and Echinodermata listed in Annex II of the Barcelona Convention live in or depend upon coralligenous habitats (UNEP/RAC/SPA, 2018). Moreover, it has been proposed that the structural and functional features of coralligenous habitat (e.g. species composition, functional groups, coverage of builders and bioeroders) should be considered as indicators in assessing the environmental quality of coastal waters and the seafloor integrity according to the Marine Strategy Framework Directive (2008/56/EC) (Cecchi, Gennaro, Piazzi, Ricevuto, \& Serena, 2014; Deter, Descamp, Ballesta, Boissery, \& Holon, 2012; Gatti et al., 201.2; Sartoretto et al., 2017). However, as is often the case in other benthic habitats, coralligenous habitat is under threat from various stressors such as sedimentation (Airoldi, 2003), mechanical damage (e.g. diving and fishing activities, Balata, Piazzi, Cecchi, \& Cinelli, 2005; Ferrigno, Appolloni, Russo, \& Sandulli, 2018; Garrabou, Sala, Arcas, \& Zabala, 1998; Linares et al., 2010), pollution (Hong, 1983), invasions by alien species (Piazzi, Balata, \& Cinelli, 2007), and global warming (Cerrano et al., 2000; Coma et al., 2009; Linares et al., 2010). Coralligenous habitat predominantly occurs in the northern part of the Mediterranean, while only a few scattered records exist from the southern coastline and the Levantine Basin, partly because of the hydrographical conditions and partly the uneven sampling efforts in the regions (Martin et al., 2014). Coralligenous habitat appears to be common in the Adriatic, Aegean, and Tyrrhenian Seas, and the Algero-Provencal Basin (Giakoumi et al., 2013). However, detailed mapping is very limited and covers only $30 \%$ of the total coastline (Martin et al., 2014). Moreover, few data exist on the ecology and diversity of coralligenous habitat beyond the north-western Mediterranean Basin. This lack of adequate data represents a big challenge for the effective management and conservation of this sensitive and vulnerable habitat (Giakoumi et al., 2013).

Another big challenge for its effective management is the choice of appropriate methods to assess and monitor the environmental status and health of the coralligenous habitat (Piazzi et al., 2019). This is a rather complex issue because: (a) data have to be collected by non-destructive methods, such as imaging and remote sensing, as destructive sampling is not a viable option for this sensitive habitat that hosts many slow-growing and late-successional species, several of which are listed as endangered or protected (Bianchi et al., 2004; RAC/SPA-UNEP/MAP, 2014); and (b) a number of rapid assessment techniques (RATs) need to be tested by as many datasets from all over the Mediterranean Sea as possible in order to decide which of the 
above-mentioned methods may provide reliable evidence to serve current research activities and management purposes. The development and application of the RATs has been discussed over recent decades because: (a) the governmental commitments to a number of European and International treaties and conventions (e.g. Marine Strategy Framework Directive, Barcelona Convention); (b) the decreasing funding resources available for environmental status assessment and monitoring; and (c) in most cases environmental managers and decision-makers need this type of biodiversity information very quickly (Féral et al., 2003).

Accordingly, the utility of optimum techniques for rapid biodiversity and environmental status assessment and monitoring has been advocated in a plethora of scientific works regarding the benthic domain (e.g. Arvanitidis et al., 2009; Clarke \& Warwick, 2001; Ferraro \& Cole, 1995; Olsgard, Somerfield, \& Carr, 1998; Somerfield \& Clarke, 1995; Vanderklift, Ward, \& Jacoby, 1996; Warwick, 1988; Warwick \& Clarke, 1998; Warwick \& Light, 2001; Warwick, Platt, Clarke, Agard, \& Gobin, 1990). Two major scientific concepts have been instrumental to the development of the baseline studies for comparisons and of the development of RATs:

(a) Biotic gradients across the Mediterranean and the Black Seas have been identified since the classic review on Mediterranean benthos by Pérès (1967). Such gradients have been observed in both shallow and deep waters (Bellan-Santini, 1985; Fredj \& Laubier, 1985) and can be the product of either the biogeography of the biota and associated with certain environmental variables (e.g. salinity and food availability, Arvanitidis et al., 2002; Surugiu et al., 2010) or of anthropogenic disturbance (Sala et al., 2012). They can be detected either in the number of taxa or in the composition of the assemblages they form.

(b) Taxonomic sufficiency concept: it has been frequently assumed that the taxonomic level required to meet the objectives of an environmental monitoring study with the least possible cost and time investment is higher than species (Ferraro \& Cole, 1995; Kingston \& Riddle, 1989; Warwick, 1988). This is because the identification of taxa down to the species level may not always be necessary to determine spatial or temporal patterns, especially when these patterns are clear, such as those established along pollution gradients (Ferraro \& Cole, 1995; Pearson \& Rosenberg, 1978; Olsgard et al., 1998; Warwick, 1988).

To date, no detailed study on the coralligenous assemblages has been performed at the ecoregion (large-Mediterranean) scale. Coordinated research effort in three countries (Turkey, Greece, and France), in the framework of the CIGESMED project (EU FP7 ERA-NET; www. cigesmed.eu), made it possible for the coralligenous habitat of four out of eight Mediterranean ecoregions (Algero-Provencal Basin, and Ionian, Aegean, and Levantine Seas; sensu Giakoumi et al., 2013; Notarbartolo di Sciara \& Agardy, 2010; Spalding et al., 2007) to be jointly studied for the first time by applying a standardized sampling protocol.

This paper aims to assess the variability of the coralligenous assemblage structure across the Mediterranean Sea ecoregions. In particular, two major hypotheses are tested: (a) that the coralligenous assemblage pattern is not homogeneous at locations across the Mediterranean ecoregions considered (biotic gradients); and (b), that the assemblage pattern does not change significantly when the information is aggregated to higher taxonomic levels (taxonomic sufficiency). Finally, the results of this study are discussed in the context of the effective management of this habitat.

\section{MATERIAL AND METHODS}

\section{1 | Study area}

Coralligenous communities were studied at nine locations distributed in the three basins (western, central, and eastern) and in four out of eight Mediterranean ecoregions (Algero-Provencal Basin, and Ionian, Aegean, and Levantine Seas) in 2014 and 2015. Continuous and generally vertically-inclined habitats were chosen at the locations: two stations in the Aegean (Turkey), Levantine (Turkey), and Ionian Seas (Greece), respectively, and three stations in the Algero-Provencal Basin (France; Figure 1). The main characteristics of the different stations are presented in Table 1. The sampling depth was 25-30 $\mathrm{m}$ at all stations, except for Zakynthos Island (Ionian Sea), where continuous coralligenous occurred only in deeper waters (38 m).

\section{2 | Sample collection}

A single campaign was organized at each station for the quantitative sampling of the coralligenous habitat using a standardized nondestructive photo-sampling protocol (David et al., 2014, 2015), which is available at the CIGESMED website (http://www.cigesmed.eu/ Characterization-by-photo-quadrats).

Custom-made quadrats, of $50 \times 50 \mathrm{~cm}$ in dimension, were used at each station for the collection of image samples, based on the experience gained from the fieldwork and analyses made for coralligenous habitats in the western and eastern Mediterranean Seas. Each image sample (sampling unit) was composed of nine quadrats placed in a $3 \times 3$ square structure, covering a total area of $2.25 \mathrm{~m}^{2}$. Three replicate image samples ( 9 quadrats each), placed ca. $10 \mathrm{~m}$ away from each other, were taken at each station. The sampling depth was the depth at which the middle quadrat was placed. In the field, samples of some species (e.g. coralline algae, sponges, bryozoans), which are difficult to identify from pictures, were taken in order to identify them under the microscope in the laboratory.

\section{3 | Sample analyses}

The image samples were subsequently analysed using the photoQuad software (Trygonis \& Sini, 2012; freely available at: http://www.mar. aegean.gr/sonarlab/photoquad/index.php). For the assessment of species composition and percentage coverage, 100 points were 


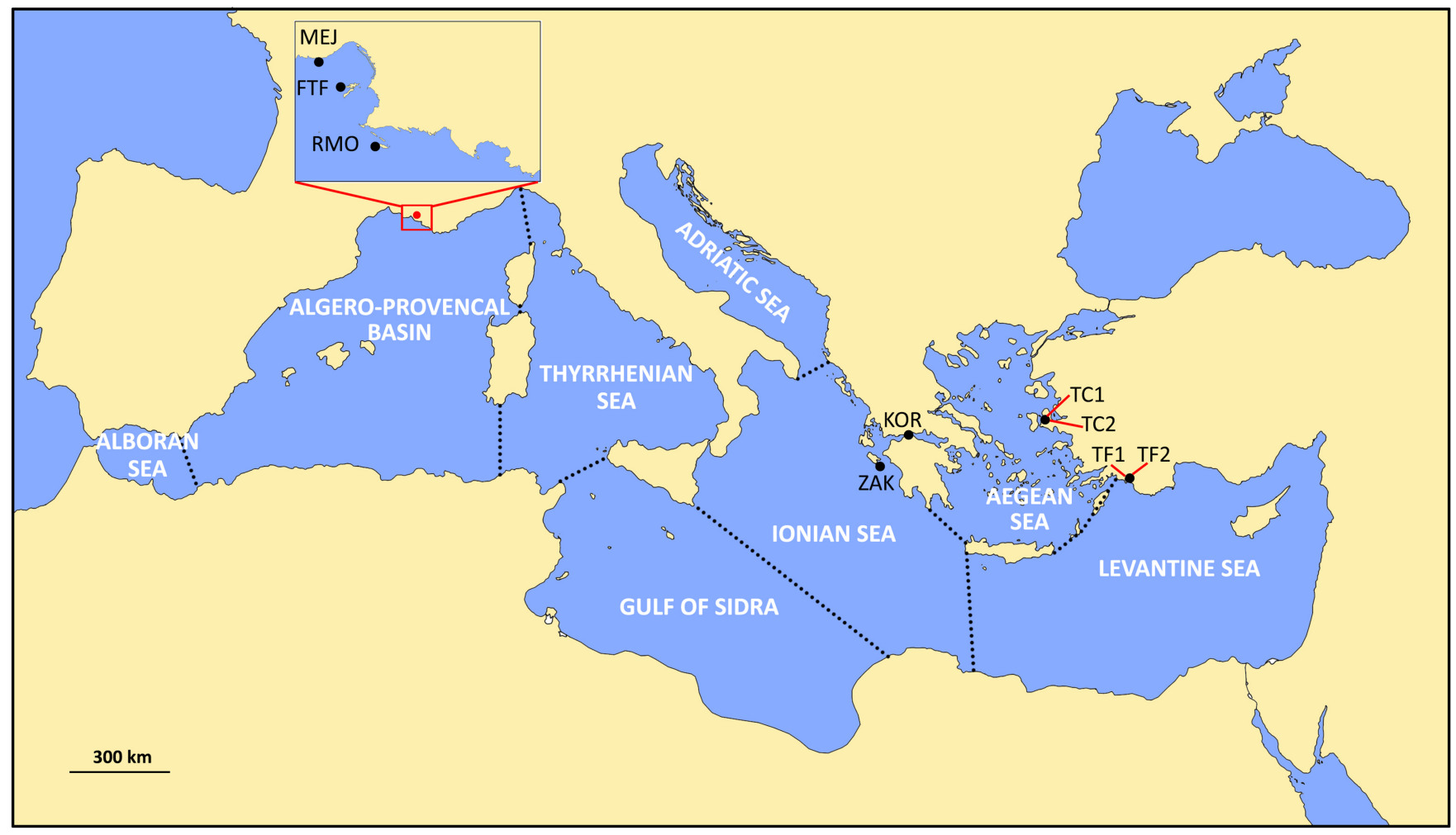

FIGURE 1 The location of sampling stations across the Mediterranean Sea

TABLE 1 Coordinates and typology of coralligenous habitats per station

\begin{tabular}{|c|c|c|c|c|c|c|c|}
\hline Stations & Codes & Coordinates & & Depth (m) & Orientation & Inclination & Rugosity \\
\hline \multicolumn{8}{|l|}{ AEGEAN SEA } \\
\hline Ildır Bay (Yarık Taş) & TC1 & $38^{\circ} 27^{\prime} 23^{\prime \prime} \mathrm{N}$ & $26^{\circ} 21^{\prime} 39^{\prime \prime} \mathrm{E}$ & 25 & $\mathrm{~N}$ & Vertical & Medium-large \\
\hline \multicolumn{8}{|l|}{ LEVANTINE SEA } \\
\hline Fethiye Bay (Afkule) & TF1 & $36^{\circ} 34^{\prime} 34^{\prime \prime} \mathrm{N}$ & $29^{\circ} 01^{\prime} 47^{\prime \prime} \mathrm{E}$ & 25 & NW & Vertical & Medium-large \\
\hline \multicolumn{8}{|l|}{ IONIAN SEA } \\
\hline Korinthiakos Bay (Lambiri) & KOR & $38^{\circ} 19^{\prime} 17^{\prime \prime} \mathrm{N}$ & $21^{\circ} 58^{\prime} 23^{\prime \prime} \mathrm{E}$ & 25 & $\mathrm{~N}$ & Vertical & Medium-large \\
\hline Zakynthos (Mavros Kavos) & ZAK & $37^{\circ} 38^{\prime} 52^{\prime \prime} \mathrm{N}$ & $20^{\circ} 50^{\prime} 46^{\prime \prime} \mathrm{E}$ & 38 & NW & Inclined/subvertical & Medium-large \\
\hline \multicolumn{8}{|l|}{ ALGERO-PROVENCAL BASIN } \\
\hline Gulf of Lions (Tiboulen du Frioul) & FTF & $43^{\circ} 16^{\prime} 49^{\prime \prime} \mathrm{N}$ & $5^{\circ} 17^{\prime} 10^{\prime \prime} \mathrm{E}$ & 28 & $\mathrm{~N}$ & Vertical & Medium-large \\
\hline
\end{tabular}

uniformly applied over each image. By focusing explicitly on the sessile taxa, a species by quadrat matrix using percentage coverage values was first created. This initial matrix was subsequently averaged by sampling station. The information included in the matrix was aggregated into five higher than species taxonomic levels: genera (79 taxa), families (60), orders (30), classes (12), and phyla (9). Then, coverage values of all taxa were square-root transformed prior to the analysis. Finally, the Bray-Curtis index (Bray \& Curtis, 1957) was applied to construct the triangular resemblance matrices.

\subsection{Statistical analyses}

The first hypothesis (biotic gradients) was tested by means of both uni- and multivariate techniques: number of taxa (S), and ShannonWeaver diversity $\left(\mathrm{H}^{\prime}\right)$ and Pielou's evenness $\left(\mathrm{J}^{\prime}\right)$ indices were calculated to explore the community species richness, diversity and equitability, respectively. Then the Permutational Analysis of Variance (PERMANOVA) using 'locations' (four levels: locations in the AlgeroProvencal Basin, and Ionian, Aegean, and Levantine Seas) as a fixed 
TAB LE 2 List of species found and their mean percent coverages per station

\begin{tabular}{|c|c|c|c|c|c|c|c|c|c|}
\hline \multirow{2}{*}{$\begin{array}{l}\text { Ecoregions } \\
\text { Stations }\end{array}$} & \multicolumn{2}{|c|}{ Aegean Sea } & \multicolumn{2}{|c|}{ Levantine Sea } & \multicolumn{2}{|c|}{ Ionian Sea } & \multicolumn{3}{|c|}{ Algero-Provencal Basin } \\
\hline & TC1 & TC2 & TF1 & TF2 & KOR & ZAK & FTF & RMO & MEJ \\
\hline \multicolumn{10}{|l|}{ CHLOROPHYTA } \\
\hline Caulerpa cylindracea Sonder, 1845 & 0.9 & 0.1 & - & - & - & - & - & - & - \\
\hline Codium bursa (Olivi) C. Agardh, 1817 & - & 0.3 & - & - & - & - & 0.1 & - & - \\
\hline Codium effusum (Rafinesque) Delle Chiaje, 1829 & - & - & - & - & - & 0.2 & - & - & 0.3 \\
\hline Flabellia petiolata (Turra) Nizamuddin, 1987 & 1.9 & 0.9 & - & - & - & - & 0.9 & 1.5 & 20.9 \\
\hline Halimeda tuna (J.Ellis \& Solander) J.V. Lamouroux, 1816 & 0.1 & 0.3 & - & - & - & - & - & - & 0.2 \\
\hline Palmophyllum crassum (Naccari) Rabenhorst, 1868 & 0.8 & 0.6 & 0.6 & 1.2 & 0.1 & 3.3 & - & 0.2 & - \\
\hline $\begin{array}{l}\text { Pedobesia simplex (Meneghini ex Kützing) M.J. Wynne \& } \\
\text { F. Leliaert, } 2001\end{array}$ & 0.2 & 0.4 & - & 7.2 & - & - & - & - & - \\
\hline Pseudochlorodesmis furcellata (Zanardini) Børgesen, 1925 & 1.3 & 0.3 & - & - & - & - & - & - & - \\
\hline Valonia utricularis (Roth) C. Agardh, 1823 & - & 0.1 & - & - & - & - & - & - & - \\
\hline Chlorophyta (sp.) & - & - & - & - & - & - & 0.2 & 0.3 & - \\
\hline \multicolumn{10}{|l|}{ RHODOPHYTA } \\
\hline Amphiroa rigida J.V. Lamouroux, 1816 & - & 0.2 & 5.3 & 0.1 & - & - & - & - & - \\
\hline Amphiroa rubra (Philippi) Woelkerling 1983 & - & - & 0.4 & 0.9 & - & - & - & - & - \\
\hline Lithophyllum sticteaforme (J.E. Areschoug) Hauck, 1877 & 19.6 & 0.1 & - & - & - & - & - & - & - \\
\hline Lithophyllum spp. & - & - & - & - & 0.4 & 2.2 & 0.2 & 2.8 & 13 \\
\hline Lithothamnion crispatum Hauck, 1878 & - & - & 7.9 & 2 & - & - & - & - & - \\
\hline Meredithia microphylla (J. Agardh) J. Agardh, 1892 & 0.1 & - & - & - & - & - & - & - & - \\
\hline $\begin{array}{l}\text { Mesophyllum alternans (Foslie) Cabioch \& M.L. Mendoza, } \\
1998\end{array}$ & - & 32.7 & 13 & 6.9 & - & - & - & - & - \\
\hline $\begin{array}{l}\text { Mesophyllum expansum (Philippi) Cabioch \& M.L. } \\
\text { Mendoza, } 2003\end{array}$ & 0.7 & - & 21.3 & 18.7 & - & - & - & - & - \\
\hline Mesophyllum philippi (Foslie) W.H. Adey, 1970 & - & - & - & 0.1 & - & - & - & - & - \\
\hline Mesophyllum spp. & - & - & - & - & 0.1 & 1.9 & - & 0.1 & - \\
\hline $\begin{array}{l}\text { Neogoniolithon hauckii (Rothpletz) R.A.Townsend \& } \\
\text { Huisman } 2018\end{array}$ & - & - & - & - & 1.8 & 0.7 & - & - & - \\
\hline Peyssonnelia dubyi P.L. Crouan \& H.M. Crouan, 1844 & 9 & 7.4 & 0.9 & 2.3 & - & - & - & - & - \\
\hline Peyssonnelia heteromorpha (Zanardini) Athanasiadis 2016 & 0.1 & 0.2 & 21 & 5.6 & - & - & - & - & - \\
\hline Peyssonnelia rosa-marina Boudouresque \& Denizot, 1973 & - & - & - & - & - & 1.1 & - & - & - \\
\hline Peyssonnelia rubra (Greville) J. Agardh, 1851 & 0.1 & 1.5 & 0.4 & 1.6 & - & 6.9 & - & - & - \\
\hline Peyssonnelia squamaria (Gmelin) Decaisne, 1842 & 21.2 & 14.8 & 8.8 & 14.4 & - & 10.1 & - & - & - \\
\hline Peyssonnelia spp. & - & - & - & - & 19.8 & 16.1 & 3.2 & 12.2 & 27 \\
\hline Sphaerococcus sp. & 0.2 & - & - & - & - & - & - & - & - \\
\hline Rhodophyta (spp.) & - & - & - & - & 2.4 & 14.2 & 1.5 & 0.5 & 0.1 \\
\hline \multicolumn{10}{|l|}{ OCHROPHYTA } \\
\hline Dictyota dichotoma (Hudson) J.V. Lamouroux, 1809 & - & 0.3 & - & - & - & - & - & - & - \\
\hline $\begin{array}{l}\text { Lobophora variegata (J.V. Lamouroux) Womersley ex E.C. } \\
\text { Oliveira, } 1977\end{array}$ & 0.3 & 0.6 & - & - & - & - & - & - & - \\
\hline Ochrophyta (sp.) & - & - & - & - & - & - & 0.4 & - & 0.1 \\
\hline TURF ALGAE & - & 1.1 & 2.4 & 0 & 6.3 & 2.6 & 0.1 & 0.6 & 7.3 \\
\hline \multicolumn{10}{|l|}{ PORIFERA } \\
\hline Acanthella acuta Schmidt, 1862 & - & - & - & - & 0.2 & - & 0.1 & - & - \\
\hline Agelas oroides (Schmidt, 1864) & 7.5 & 1.7 & 0.3 & 2 & 6.2 & 5.3 & 0.2 & 0.3 & 0.1 \\
\hline Aplysina aerophoba (Nardo, 1833) & - & 0.2 & 0.1 & 0.1 & - & - & - & - & - \\
\hline Aplysina cavernicola (Vacelet, 1959) & - & 0.1 & - & - & - & - & 0.2 & - & - \\
\hline
\end{tabular}


TABLE 2 (Continued)

\begin{tabular}{|c|c|c|c|c|c|c|c|c|c|}
\hline \multirow{2}{*}{$\begin{array}{l}\text { Ecoregions } \\
\text { Stations }\end{array}$} & \multicolumn{2}{|c|}{ Aegean Sea } & \multicolumn{2}{|c|}{ Levantine Sea } & \multicolumn{2}{|c|}{ Ionian Sea } & \multicolumn{3}{|c|}{ Algero-Provencal Basin } \\
\hline & TC1 & TC2 & TF1 & TF2 & KOR & ZAK & FTF & RMO & MEJ \\
\hline Aplysilla rosea (Barrois, 1876) & - & - & - & - & 0.1 & - & - & - & - \\
\hline Aplysilla sulfurea (Schulze, 1878) & - & - & - & - & - & - & - & 0.1 & - \\
\hline Axinella cannabina (Esper, 1794) & - & - & - & - & 2.1 & - & - & - & - \\
\hline Axinella damicornis (Esper, 1794) & 0.3 & 0.1 & - & - & 0.1 & - & 1.2 & 0.7 & 0.2 \\
\hline Axinella polypoides Schmidt, 1862 & - & 0.3 & - & 0.1 & - & - & 0.2 & 0.1 & - \\
\hline Axinella verrucosa (Esper, 1794) & - & - & - & - & - & - & 0.3 & 0.1 & 0.1 \\
\hline Axinella spp. & - & - & 0.1 & - & - & 0.3 & - & - & - \\
\hline Cacospongia mollior Schmidt, 1862 & - & - & - & - & - & 0.1 & - & - & - \\
\hline Corticium candelabrum Schmidt, 1862 & - & - & - & - & 0.1 & - & - & - & - \\
\hline Chondrilla nucula Schmidt, 1862 & - & 0.1 & - & - & - & - & - & - & - \\
\hline Chondrosia reniformis Nardo, 1847 & - & 2.7 & - & 0.2 & 4.3 & 0.9 & - & - & 0.1 \\
\hline Cliona celata Grant, 1826 & 0.6 & 0.1 & - & 0.1 & 0.1 & - & - & - & - \\
\hline Cliona schmidtii (Ridley, 1881) & 0.1 & 0.1 & - & 0.1 & 0.3 & - & - & - & - \\
\hline Cliona viridis (Schmidt, 1862) & - & - & - & 0.1 & 0.2 & 0.3 & - & - & - \\
\hline Crambe crambe (Schmidt, 1862) & 0.1 & - & - & - & - & - & - & - & - \\
\hline Dictyonella incisa (Schmidt, 1880) & - & - & - & - & 0.7 & - & - & - & - \\
\hline Dictyonella sp. & - & - & - & - & - & - & - & 0.2 & 0.2 \\
\hline Dysidea fragilis (Montagu, 1814) & - & - & - & - & 0.3 & 0.3 & - & 0.2 & - \\
\hline Haliclona (reniera) aquaeductus (Schmidt, 1862) & - & - & - & - & - & - & 0.1 & - & - \\
\hline Haliclona (halichoclona) fulva (Topsent, 1893) & 0.1 & 0.2 & - & - & 0.5 & 0.1 & 0.8 & - & - \\
\hline Haliclona (soestella) mucosa (Griessinger, 1971) & - & - & - & - & 0.3 & 0.1 & 0.5 & 0.4 & 0.1 \\
\hline Haliclona sp. & - & - & - & - & - & 0.1 & - & - & - \\
\hline Hemimycale columella (Bowerbank, 1874) & - & - & - & - & - & 0.1 & - & - & - \\
\hline Hexadella pruvoti Topsent, 1896 & - & - & - & - & 0.2 & - & - & - & - \\
\hline Hexadella racovitzai Topsent, 1896 & - & - & - & - & 0.2 & - & - & - & - \\
\hline Ircinia variabilis (Schmidt, 1862) & - & - & - & - & 2 & - & - & - & - \\
\hline Ircinia sp. & - & 0.1 & - & - & - & - & - & - & - \\
\hline $\begin{array}{l}\text { Oscarella balibaloi Pérez, Ivanisevic, Dubois, Pedel, } \\
\text { Thomas, Tokina \& Ereskovsky, } 2011\end{array}$ & - & - & - & - & 3.4 & - & - & - & - \\
\hline $\begin{array}{l}\text { Oscarella imperialis Muricy, Boury-Esnault, Bézac \& } \\
\text { Vacelet, } 1996\end{array}$ & - & - & - & - & - & 0.1 & - & - & - \\
\hline Oscarella lobularis (Schmidt, 1862) & - & - & - & - & - & - & 7.1 & - & - \\
\hline Oscarella tuberculata (Schmidt, 1868) & - & - & - & - & 0.1 & - & 0.3 & - & - \\
\hline Oscarella sp. & - & - & - & - & - & - & 1.2 & 0.4 & - \\
\hline Penares sp. & - & - & - & - & - & 0.2 & - & - & - \\
\hline Petrosia (petrosia) ficiformis (Poiret, 1789) & - & - & - & 0.3 & 0.2 & - & 0.7 & - & - \\
\hline Phorbas sp. & 0.6 & - & - & - & - & - & - & - & - \\
\hline Phorbas fictitius (Bowerbank, 1866) & - & 0.1 & - & - & - & - & - & - & - \\
\hline Phorbas tenacior (Topsent, 1925) & 1 & 1 & - & 0.1 & 3.2 & - & 0.2 & 0.1 & 0.2 \\
\hline Pleraplysilla spinifera (Schulze, 1879) & 0.1 & - & - & - & 1.5 & 0.5 & - & - & - \\
\hline Prosuberites longispinus Topsent, 1893 & - & - & - & - & 0.6 & - & - & - & - \\
\hline Sarcotragus sp. & 0.1 & - & - & - & - & - & - & - & - \\
\hline Sarcotragus foetidus Schmidt, 1862 & - & - & - & - & - & 0.4 & - & - & - \\
\hline Sarcotragus spinosulus Schmidt, 1862 & 1 & 0.1 & - & - & - & - & - & - & - \\
\hline Spirastrella cunctatrix Schmidt, 1868 & 10.8 & 2 & 0.6 & 3.7 & 8.8 & 6.4 & - & - & - \\
\hline
\end{tabular}


TABLE 2 (Continued)

\begin{tabular}{|c|c|c|c|c|c|c|c|c|c|}
\hline \multirow{2}{*}{$\frac{\text { Ecoregions }}{\text { Stations }}$} & \multicolumn{2}{|c|}{ Aegean Sea } & \multicolumn{2}{|c|}{ Levantine Sea } & \multicolumn{2}{|c|}{ Ionian Sea } & \multicolumn{3}{|c|}{ Algero-Provencal Basin } \\
\hline & TC1 & TC2 & TF1 & TF2 & KOR & ZAK & FTF & RMO & MEJ \\
\hline Spongia (spongia) officinalis Linnaeus, 1,759 & - & - & - & - & 0.2 & - & - & - & - \\
\hline Porifera (spp.) & 0.1 & - & - & - & - & 0.3 & 10.8 & 8.5 & 0.7 \\
\hline \multicolumn{10}{|l|}{ CNIDARIA } \\
\hline Alcyonium coralloides (Pallas, 1766) & - & - & - & - & - & - & - & 0.1 & 0.7 \\
\hline Caryophyllia inornata (Duncan, 1878) & - & - & - & - & 1.9 & - & - & - & - \\
\hline Corallium rubrum (Linnaeus, 1758) & - & - & - & - & - & - & 0.1 & 0.3 & 0.7 \\
\hline Cladocora caespitosa (Linnaeus, 1767) & - & - & - & - & - & - & 0.1 & - & - \\
\hline Eudendrium sp. & - & - & - & - & - & - & - & - & 0.1 \\
\hline Eunicella cavolini (Koch, 1887) & - & - & - & - & - & - & 0.2 & 0.1 & 10.1 \\
\hline Hoplangia durotrix Gosse, 1860 & - & - & - & - & 3 & - & 1.1 & 1.3 & - \\
\hline Leptopsammia pruvoti Lacaze-Duthiers, 1897 & 0.5 & 0.2 & - & - & 0.4 & 2.1 & 2.5 & 2.6 & 0.1 \\
\hline Leptogorgia sarmentosa (Esper, 1789) & - & - & - & - & - & - & 0.1 & - & - \\
\hline Madracis pharensis (Heller, 1868) & 0.1 & - & - & 0.1 & 2.5 & 0.1 & - & - & - \\
\hline Paramuricea clavata (Risso, 1826) & - & - & - & - & - & - & 16.7 & 28.2 & 0.2 \\
\hline Parazoanthus axinellae (Schmidt, 1862) & - & - & - & - & - & - & 10.8 & 0.1 & 0.2 \\
\hline Polycyathus muellerae (Abel, 1959) & - & - & - & - & 1.7 & - & - & - & - \\
\hline Phyllangia americana mouchezii (Lacaze-Duthiers, 1897) & - & - & - & - & - & - & 0.1 & - & - \\
\hline Hydrozoa (sp.) & - & - & - & - & - & 0.1 & - & - & - \\
\hline Scleractinia (sp.) & - & - & - & - & - & - & 0.3 & 0.1 & - \\
\hline Octocorallia (sp.) & - & - & - & - & - & - & 0.1 & - & - \\
\hline
\end{tabular}

\section{PLATYHELMINTHES}

Yungia aurantiaca (Delle Chiaje, 1822)

\section{POLYCHAETA}

Hermodice carunculata (Pallas, 1766)

Protula tubularia (Montagu, 1803)

Salmacina sp./Filograna sp.

Serpulidae (sp.)

\section{MOLLUSCA}

Lithophaga lithophaga (Linnaeus, 1758)

Ostrea sp.

Peltodoris atromaculata Bergh, 1880

Rocellaria dubia (Pennant, 1777)

\section{BRYOZOA}

Adeonella/Smittina spp.

Adeonella calveti (Canu \& Bassler, 1930)

Beania magellanica (Busk, 1852)

Caberea boryi (Audouin, 1826)

Cellaria sp.

Celleporina caminata (Waters, 1879)

Dentiporella sardonica (Waters, 1879)

Myriapora truncata (Pallas, 1766)

Pentapora fascialis (Pallas, 1766)

Reteporella sp.

Reteporella grimaldii (Jullien, 1903)

Rhynchozoon neapolitanum Gautier, 1962

0.1

0.1

0.1

0.1

0.89

0.04

0.1

0.1

0.1

0.2 
TABLE 2 (Continued)

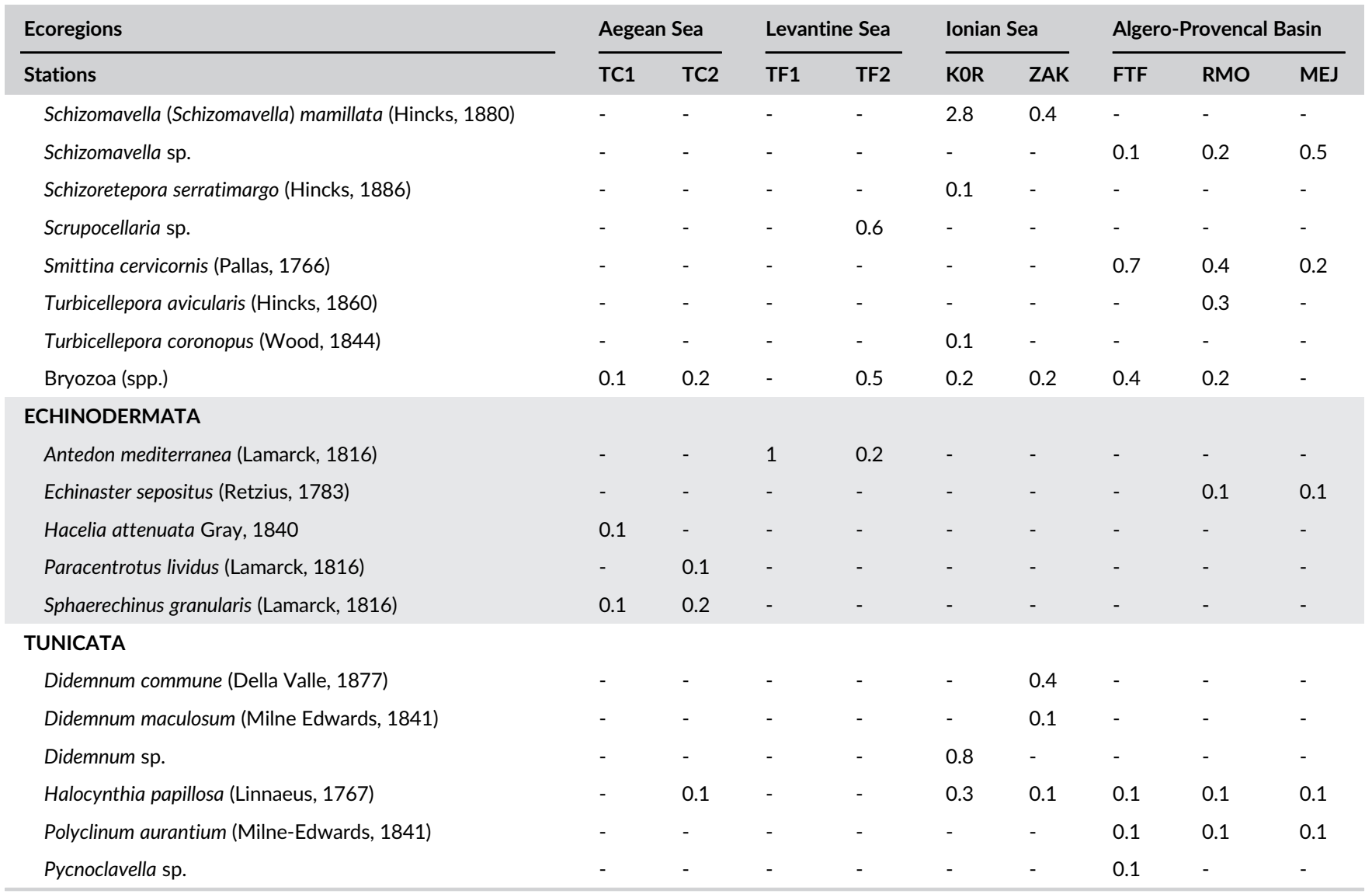

factor (categorical variable) was applied to check for differences in the univariate community measures. The assemblage multivariate pattern was explored and visualized using the principal coordinate analysis (PCoA) (Torgerson, 1958), applied on the Bray-Curtis resemblance matrices at the species level and at the two levels of replication: image sample and location. PERMANOVA was carried out to test for potential differences in the coralligenous assemblage structure among locations. Finally, the Similarity Percentages Analysis (SIMPER) (Clarke, 1993) was applied to the species matrices in order to identify those species which significantly contributed to the (dis)similarity of groups of samples in the coralligenous assemblages.

The second hypothesis (taxonomic sufficiency) was tested by means of the second-stage multidimensional scaling (MDS) (Somerfield \& Clarke, 1995). This technique can visualize changes in coralligenous assemblage patterns deriving from different taxonomic levels at the two different spatial levels (i.e. image sample and station). The resemblance matrices of species coverage values, at each of the six taxonomic levels considered here, were first constructed. These matrices were then correlated using a rank correlation between their corresponding elements (samples). The significance of these inter-matrix correlations was tested by using the RELATE technique (Clarke \& Gorley, 2006). Subsequently, a second-stage resemblance matrix was constructed, which can be used to display interrelationships between patterns derived from different taxonomic levels.

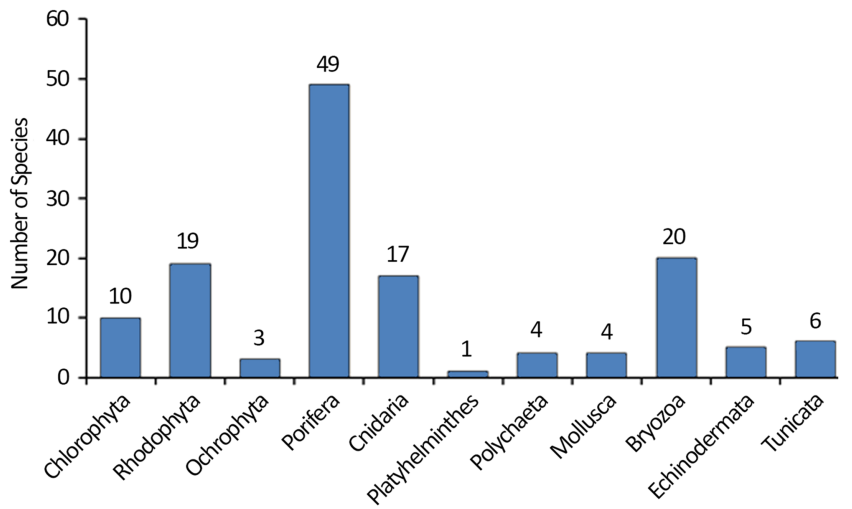

FIGURE 2 Total number of species recorded per taxonomic group at all stations

Finally, the non-metric MDS algorithm was applied on this secondstage resemblance matrix to visualize to what extent patterns deriving from the different taxonomic levels are close to each other or not. Finally, in order to test for the significance of the differences in the groups of either images or stations, at all levels of the aggregated information, that is from species to phyla, an analysis of similarities (ANOSIM) was applied (Clarke, 1993). All analyses were performed using the PRIMER v7 package (Clarke \& Gorley, 2006; Clarke, Gorley, \& Warwick, 2014). 


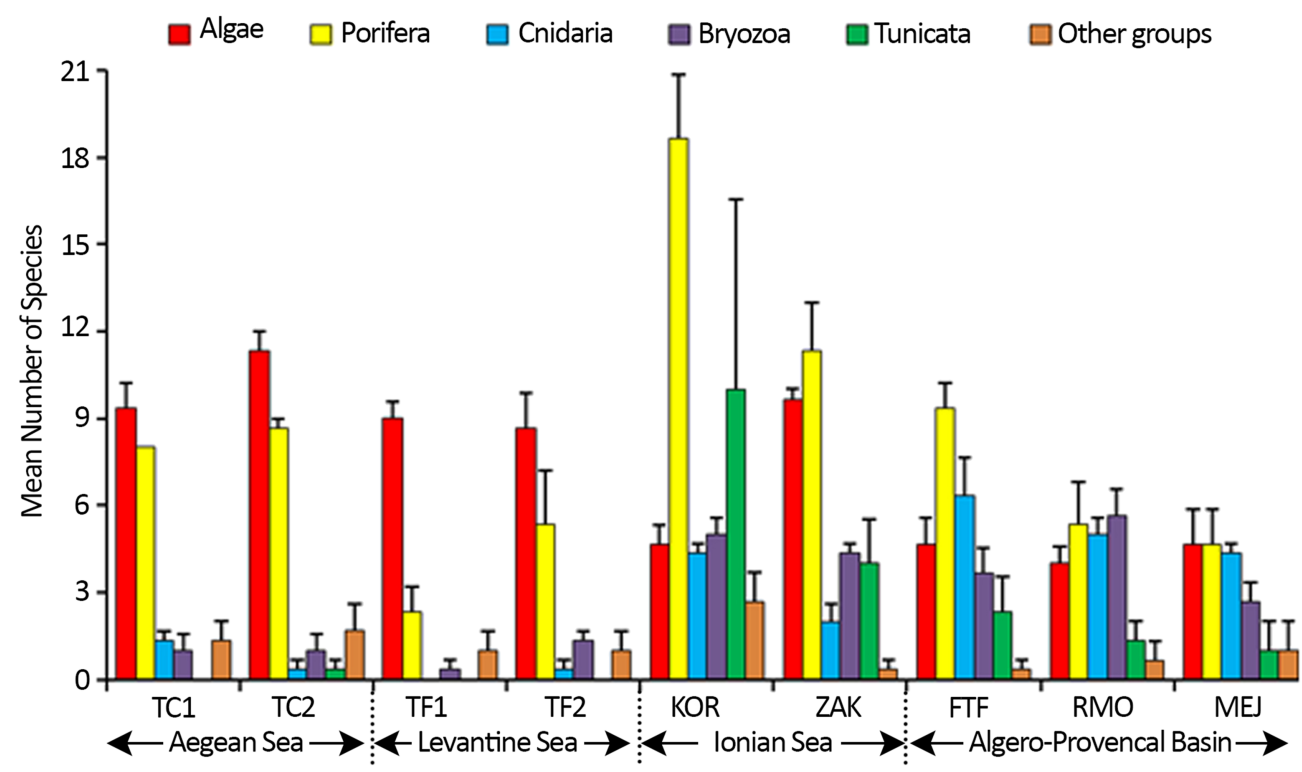

FIGURE 3 Average number of species recorded per station. Bar denotes standard error

TAB LE 3 Overall and pairwise PERMANOVA tests applied on the number of species of the main taxonomic groups. Locations in ecoregions: 1. Aegean Sea, 2. Levantine Sea, 3. Ionian Sea, 4. Algero-Provencal Basin

\begin{tabular}{|c|c|c|c|c|c|c|c|c|c|c|c|c|c|c|c|c|}
\hline $\begin{array}{l}\text { Source of } \\
\text { variation }\end{array}$ & \multicolumn{4}{|c|}{ Algae } & \multicolumn{3}{|c|}{ Porifera } & \multicolumn{3}{|c|}{ Cnidaria } & \multicolumn{3}{|c|}{ Bryozoa } & \multicolumn{3}{|c|}{ Tunicata } \\
\hline Locations & 3 & 47.6 & 13.5 & $*$ & 140 & 13.9 & * & 39.3 & 26.6 & * & 25.5 & 16.2 & $*$ & 65 & 4.3 & $*$ \\
\hline \multicolumn{17}{|c|}{ Pairwise comparisons of locations } \\
\hline & & $t$ & $P$ & & $t$ & $P$ & & $t$ & $P$ & & $t$ & $P$ & & $t$ & $P$ & \\
\hline 1 vs 3 & & 2.35 & ns & & 3.23 & $*$ & & 3.45 & $* *$ & & 7.41 & * & & 2.07 & * & \\
\hline 1 vs 4 & & 7.41 & * & & 0.15 & ns & & 6.34 & * & & 3.75 & $* *$ & & 2.07 & ns & \\
\hline 2 vs 3 & & 1.27 & ns & & 4.76 & $*$ & & 4.81 & $*$ & & 8.45 & $*$ & & 2.12 & * & \\
\hline 2 vs 4 & & 5.77 & * & & 1.76 & ns & & 7.65 & $*$ & & 4.03 & * & & 2.36 & ns & \\
\hline
\end{tabular}

Abbreviations: ns, non-significant.

${ }^{*} P<0.01,{ }^{* *} P<0.05$.

\section{3 | RESULTS}

\section{1 | Testing of the biotic-gradients hypothesis}

The analysis of the photo-quadrat samples revealed the presence of 138 species (95 sessile and 43 sedentary species) belonging to 11 taxonomic groups (Chlorophyta, Rhodophyta, Ochrophyta, Porifera, Cnidaria, Bryozoa, Polychaeta, Platyhelminthes, Mollusca, Echinodermata, and Tunicata) across all studied stations (Table 2; Figure 2). Porifera (49 species) and Bryozoa (20 species) were the dominant groups in terms of the number of species. Algae (including Chlorophyta, Rhodophyta, and Ochrophyta) were represented by 30 species. The presence of other groups was limited to a few species. Only one alien species (Caulerpa cylindracea) was found at station TC1, covering $3 \%$ of the total area.
Porifera appeared to be a diverse group in all locations, reaching a maximum (33 species) at the location in the Ionian Sea. Rhodophytes attained highest species richness values at the locations in the Aegean and Levantine Seas (13 species), while the highest number of cnidarian species (13) was found at the location in the Algero-Provencal ecoregion (Figure 3). Only 11 species were shared by all the Mediterranean locations studied. Some stations (KOR and MEJ) had high coverage of turf algae, which were composed of small green and brown filamentous species, as observed in the photo-quadrats.

The number of species in each sampling unit (image sample) ranged from 10 (station TF2) to 42 (station KOR). The number of species of the most abundant, in terms of coverage, taxonomic groups of coralligenous assemblages varied significantly among the Mediterranean locations studied (PERMANOVA, $P<0.01$; Table 3 ). 


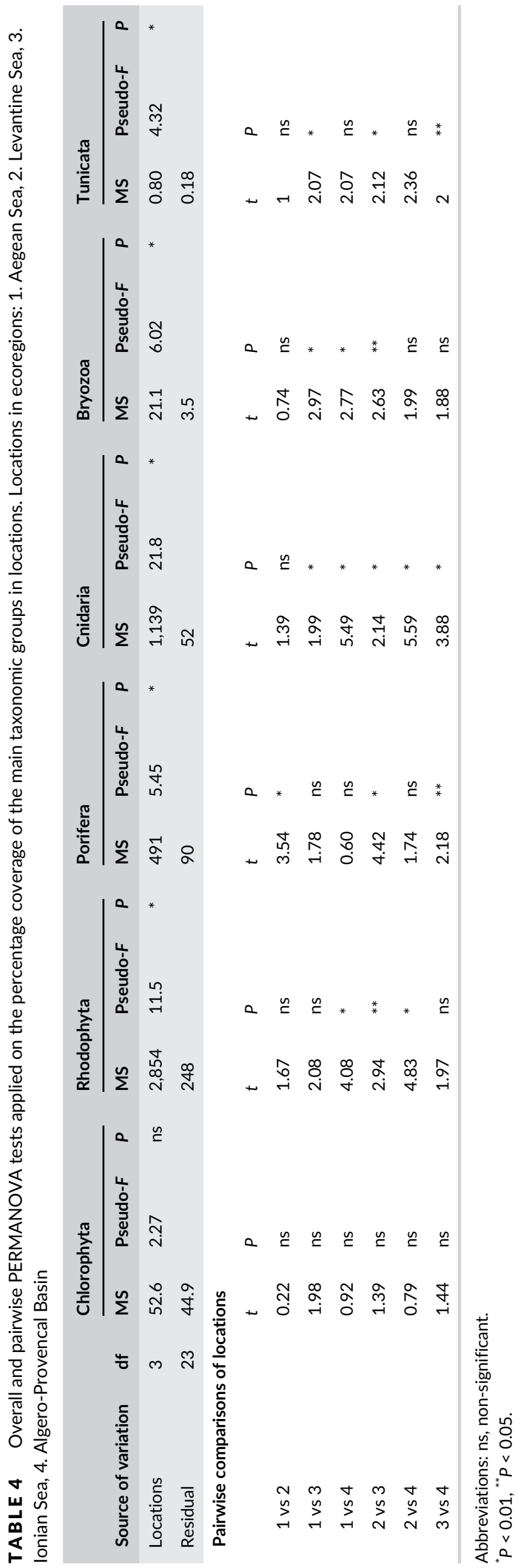

The pair-wise tests revealed that the number of species of algae did not change significantly among the neighbouring locations (Aegean, Levantine, and Ionian Seas). The average number of algae was always higher at the locations in the eastern Mediterranean (Aegean and Levantine Seas), the number of sponge species was always higher in the Ionian Sea, and the numbers of cnidarian and bryozoan species were higher in the western Mediterranean (Figure 3).

The coverage of the taxonomic groups in coralligenous habitats differed significantly among locations in the ecoregions (PERMANOVA, $P<0.01$; Table 4). The pairwise tests showed that the percentage coverage of rhodophytes differed significantly in distant locations. The cnidarian coverage differed significantly among locations, with the exception of the Aegean and Levantine Seas. The average coverage of rhodophytes was higher than $50 \%$ at five stations (TC1, TC2, TF1, TF2, and ZAK) and reached up to $80 \%$ at station TF1 (Figure 4). The highest coverage of Porifera was at station KOR (36\%), while for Cnidaria, stations FTF (32\%) and RMO (33\%) had the highest coverage. Turf algae were observed at all stations (except for TC1) and their highest maximum and mean coverage values were encountered at MEJ (max: 16\%, mean: $6.3 \%$ ) and KOR (max: $12 \%$, mean: 7.3\%; Figure 4).

Differences in species richness $(\mathrm{S})$, diversity $\left(\mathrm{H}^{\prime}\right)$ and evenness $\left(\mathrm{J}^{\prime}\right)$ indices among locations were all significant (PERMANOVA, $P<0.01$; Table 5). Interestingly, the community parameters estimated in two distant locations (Aegean Sea and Algero-Provencal Basin) were not statistically different (pairwise tests). The maximum mean number of species $(S=38)$, diversity index value $\left(H^{\prime}=4\right)$ and evenness index value $\left(J^{\prime}=0,76\right)$ were calculated at station KOR. The lonian stations (KOR and ZAK) presented the highest mean values of $\mathrm{S}, \mathrm{H}^{\prime}$ and $\mathrm{J}^{\prime}$, while the Algero-Provencal stations the lowest values of $\mathrm{H}^{\prime}$ and $\mathrm{J}^{\prime}$ (Figure 5).

The coralligenous assemblage composition of the locations in the four ecoregions studied were significantly different (PERMANOVA, Pseudo-F: 13.2, $P<0.01$ ). The pair-wise tests indicated that all locations significantly differ from each other $(t>2.87, P<0.01)$. The application of the PCoA showed that there are four distinct groups of samples, corresponding to the locations sampled (Figure 6). The first two axes of the PCoA graph explained $57 \%$ of total variance. The average similarity of stations within each of the Mediterranean ecoregions was higher than $40 \%$, reaching $63 \%$ in the Levantine Sea, $57 \%$ in the Aegean Sea, $56 \%$ in the Ionian Sea, and $42 \%$ in the Algero-Provencal Basin (Table 6), which is indicative of a possible gradient across the ecoregions considered in this study. The SIMPER analysis indicated that some sponge and rhodophyte species contributed much to the dissimilarity of assemblages among the ecoregions (Table 6). The species that have the longer vectors along the first PCoA axis (multiple correlation $-0.3>R>0.3$ ) were Peyssonnelia squamaria $(R=0.4)$, Mesophyllum alternans $(R=0.36)$, Peyssonnelia spp. $(R=-0.36)$, and $M$. expansum $(R=0.31)$; those that have the longer vectors along the second PCoA axis were Spirastrella cunctatrix $(R=0.39)$, Agelas oroides $(R=0.32)$, and $P$. clavata $(R=-0.30)$. 


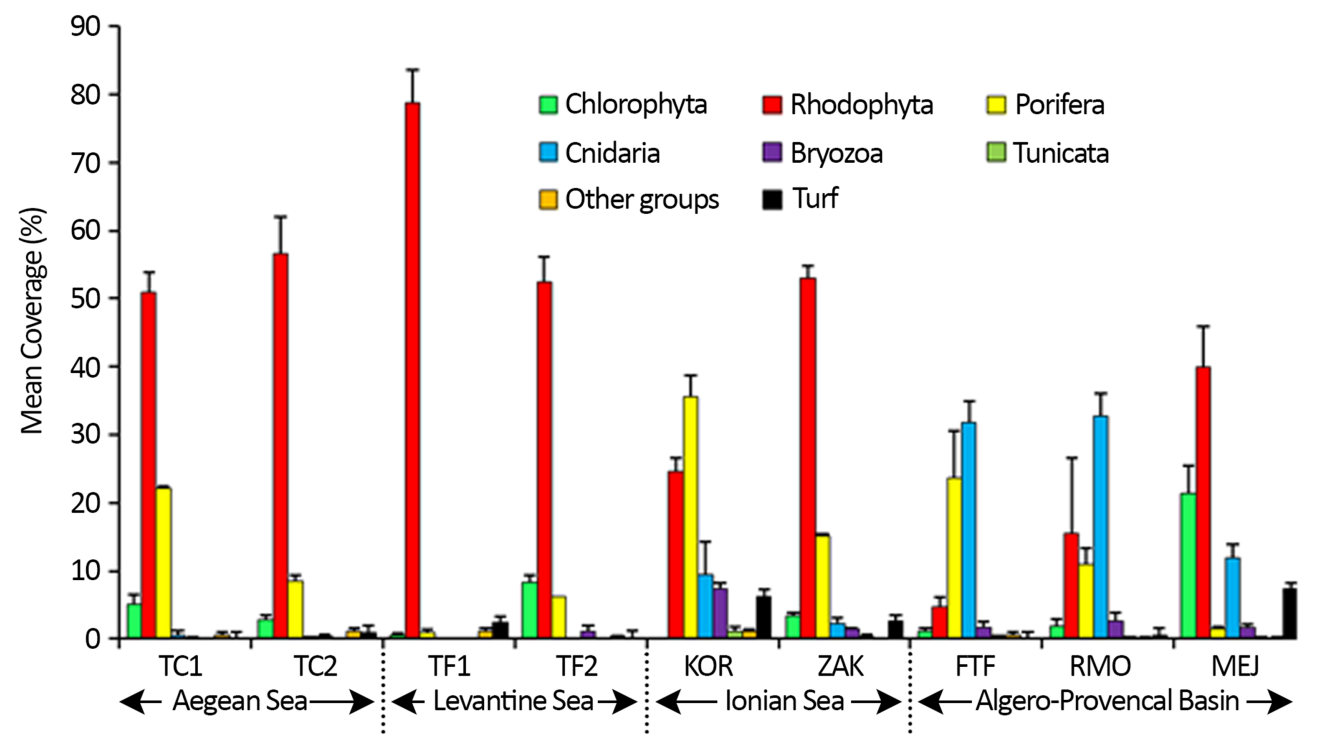

FIGURE 4 Average percentage coverage of taxonomic groups and algal turf recorded per station. Bar denotes standard error

TAB LE 5 Overall and pairwise PERMANOVA tests applied on the community parameters. Locations in ecoregions: 1. Aegean Sea, 2. Levantine Sea, 3. Ionian Sea, 4. Algero-Provencal Basin

\begin{tabular}{|c|c|c|c|c|c|c|c|c|c|c|}
\hline Source of variation & df & \multicolumn{3}{|c|}{ Number of species } & \multicolumn{3}{|c|}{ Diversity index } & \multicolumn{3}{|c|}{ Evenness index } \\
\hline Locations & 3 & 379 & 18.9 & * & 1.91 & 21.6 & * & 0.05 & 14.3 & * \\
\hline Residual & 23 & 20 & & & 0.09 & & & 0.003 & & \\
\hline \multicolumn{11}{|c|}{ Pairwise comparisons of locations } \\
\hline & & $t$ & $P$ & & $t$ & $P$ & & $t$ & $P$ & \\
\hline 1 vs 3 & & 4.88 & $* *$ & & 6.39 & $* *$ & & 4.79 & ** & \\
\hline 1 vs 4 & & 0.05 & ns & & 1.12 & ns & & 1.11 & ns & \\
\hline 2 vs 3 & & 6.7 & $* *$ & & 5.61 & $* *$ & & 0.58 & ns & \\
\hline 2 vs 4 & & 2.9 & $* *$ & & 1.33 & ns & & 4.37 & ** & \\
\hline
\end{tabular}

Abbreviations: ns, non-significant.

${ }^{*} P<0.01,{ }^{* *} P<0.05$.

\section{2 | Testing of the taxonomic sufficiency hypothesis}

When the information was aggregated to higher taxonomic levels, the ecoregion trend remained similar although smoother from the level of orders and upwards. However, the ANOSIM tests were always significant at all levels from species to phyla at the ecoregion scale, based on image samples (Data S1). On the plots of the second-stage MDS (Figure 7), patterns derived from the species level appeared to be closer to those derived from genera and families than to those from the remaining taxonomic levels. This similarity trend remained the same at both scales: image and station. The RELATE technique applied to every pair of the resemblance matrices deriving from the six taxonomic levels considered showed that they all are positively and significantly correlated to each other (Data S2). Resemblance matrices of species and phyla were always the least correlated ( 0.78 at the image and 0.66 at the station scale), while those of genera and families were the highest correlated to each other (0.97 at image and 0.98 at the station scale). These results mean that as the information is aggregated from species to phyla the multivariate pattern between them differs maximally by $37 \%$, while those patterns between species and genera and species and families differ maximally by $27 \%$.

\section{4 | DISCUSSION}

The present study shows that coralligenous assemblages are different in the various Mediterranean ecoregions, investigated in this study. This result is in agreement with previous studies, confirming the high ecological and biodiversity importance attributed to coralligenous habitats (Ballesteros, 2006; Hong, 1982; Laubier, 1966), as well as the high value of the ecosystem services they provide to mankind (e.g. food, carbon sequestration, water filtration, coastline stabilization) (Thierry De Ville D'Avray, 2018). However, coralligenous habitats 

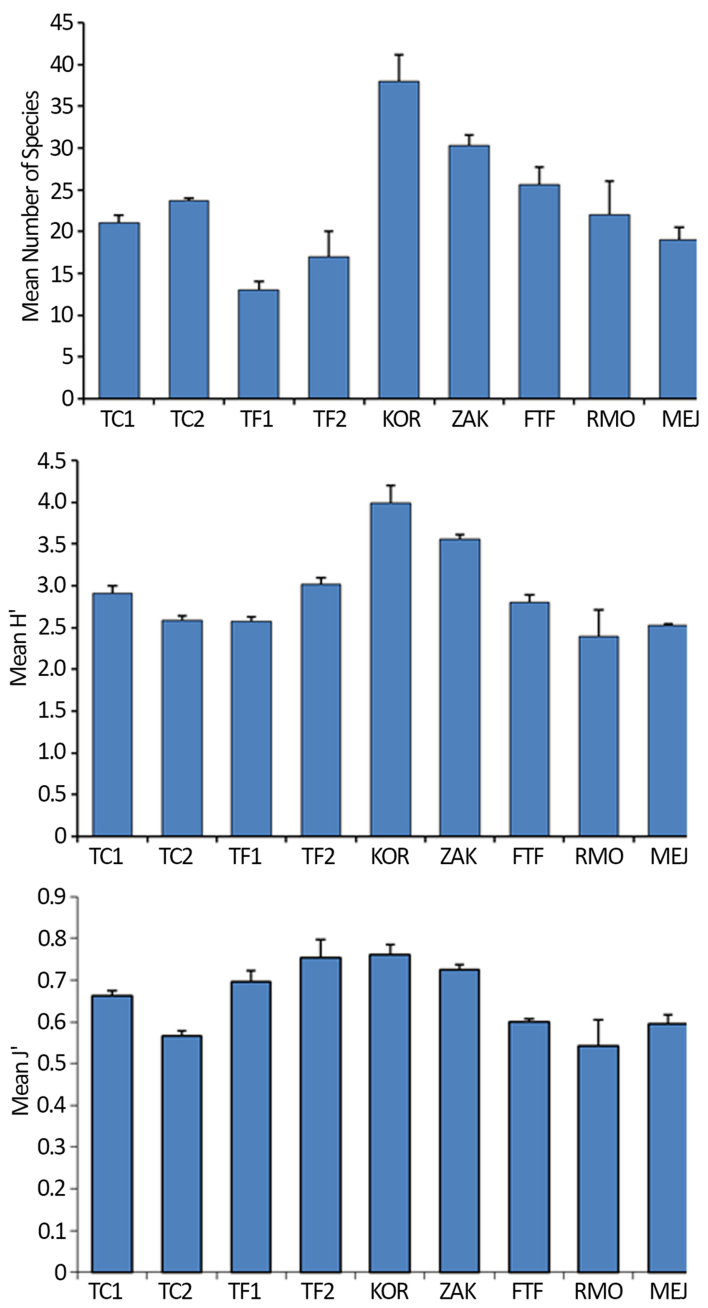

FIGURE 5 Average values of the number of species (S), the diversity index $\left(\mathrm{H}^{\prime}\right)$, and the evenness index $\left(\mathrm{J}^{\prime}\right)$. Bar denotes standard error

are more diversified than estimated as, due to the methodology applied (i.e. photo-quadrat method), a number of species living in crevices of biogenic constructions were not determined. The number of taxa belonging to each taxonomic group varied among basins; sponges were the most diversified at all studied locations, followed by bryozoans, rhodophytes, and cnidarians. However, different taxa dominated the different locations (ecoregions) of the Mediterranean Sea. Shallow coralligenous assemblages (at 25-50 m) in the eastern Mediterranean are known to be composed of a richer sponge fauna, while large alcyonarians and gorgonians are rare or absent ('facies oriental', Pérès \& Picard, 1958; but see Piazzi et al., 2019; Sini, Kipson, Linares, Koutsoubas, \& Garrabou, 2015). The present study confirmed this finding that sponges dominated the eastern Mediterranean coralligenous habitats, with Spirastrella cunctatrix and Agelas oroides the most characteristic species.

The absence of erect bryozoans (e.g. Myriapora truncata, Pentapora fascialis, and Reteporella grimaldii), which are abundant in the western Mediterranean coralligenous habitats (Casoli et al., 2017), also characterized the Turkish stations of the eastern Aegean and the northern Levantine Sea, as is the case in other areas of the north
Aegean Sea (Sini, Garrabou, \& Koutsoubas, 2014) and the north Adriatic Sea (Casellato \& Stefanon, 2008). It is known that the presence of suspension feeders in coralligenous habitats largely depends on current strength and availability of food (Ballesteros, 2006; Longo et al., 2018). Gorgonians are generally reported to be abundant in areas rich in suspended organic matter, while sponges, bryozoans and scleractinian corals prefer more oligotrophic waters (Gili \& Ballesteros, 1991).

Sini et al. (2014) reported that Porifera were the most diverse taxonomic group in the coralligenous habitat of the Aegean Sea, representing an overall coverage of $28 \%$, with Agelas oroides, Chondrosia reniformis, Crambe crambe, and Spirastrella cunctatrix making the greatest contribution. The widespread sponge species Agelas oroides and Spirastrella cunctatrix in the eastern Mediterranean species were also common in coralligenous habitats of the Tyrrhenian Sea (Ferdeghini, Acunto, Cocito, \& Cinelli, 2000). In the north Aegean Sea, Antoniadou, Voultsiadou, and Chintiroglou (2006) showed that the frequently distributed and abundant species in the coralligenous habitats were A. oroides (max. 30 ind. $\mathrm{m}^{-2}$ ) and Diplastrella bistellata (max. 22 ind. $\mathrm{m}^{-2}$ ). Sini et al. (2014) reported that Porifera were the most diverse taxonomic group in the coralligenous habitat of the Aegean Sea, representing an overall coverage of $28 \%$, with Agelas oroides, Chondrosia reniformis, Crambe crambe and Spirastrella cunctatrix making the greatest contribution. However, it has been emphasized that endolithic sponges represent higher species richness and biomass when compared to those in the epibenthic layer of the coralligenous habitat (Calcinai et al., 2015). Therefore, the species number encountered in the present study seems to represent only a fraction of the sponge inventory of this habitat.

The importance of cnidarians in the coralligenous assemblages differed across the localities studied; their average coverage in the Algero-Provencal Basin was almost six times higher than those in the Aegean and Levantine Seas, and two times higher than that in the Ionian Sea. The gorgonians were totally lacking from the eastern Mediterranean stations, whereas two large-sized species Paramuricea clavata and Eunicella cavolini occupied $>18 \%$ of total area of coralligenous habitats in the Algero-Provencal Basin. It is known that gorgonian assemblages are rarely reported in areas shallower than $40 \mathrm{~m}$ depth in the eastern Mediterranean (Çinar, Gönülal, \& Öztürk, 2018; Salomidi, Smith, Katsanevakis, Panayotidis, \& Papathanassiou, 2009). However, facies with E. cavolini and $P$. clavata occur widely in the north Aegean Sea (Gerovasileiou, Sini, Poursanidis, \& Koutsoubas, 2009; Sini et al., 2015). Gorgoniandominated habitats provide a three-dimensional complexity to the epibenthic layer that forms a number of microhabitats, increasing the local diversity (Cerrano et al., 2010; True, 1970). Gorgonians can also reduce the growth of erect algae and favour the settlement of encrusting algae and sessile invertebrates (Ballesteros, 2006; Laubier, 1966). The disappearance of gorgonians from coralligenous assemblages might cause a shift from assemblages formed by encrusting coralline algae to filamentous algae assemblages, decreasing complexity and resilience of coralligenous habitats (Ponti et al., 2014). 


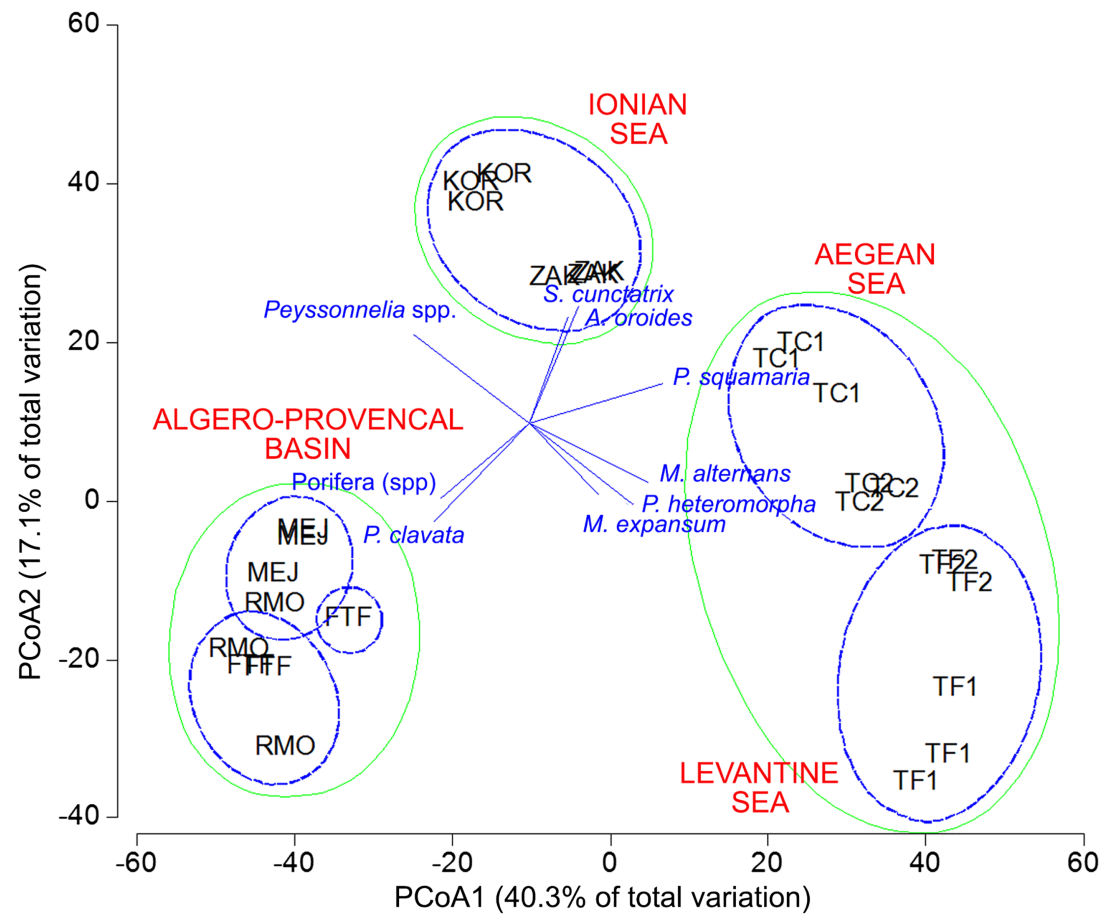

FIGURE 6 Principal coordinate analysis (PCoA) showing the similarity among replicated samples of stations, based on coverage data of all species. Green lines indicate a similarity level of $20 \%$, blue lines indicate a similarity level of $40 \%$. Vectors represent the species that relatively highly correlated with PCoA1 and PCoA2 (multiple correlation, $r>0.3$ )

TAB LE 6 Results from SIMPER Analysis showing the species contributing the most (>7\%) to the formation of groups indicated in Figure 10

\begin{tabular}{|lllll} 
& Aegean Sea & Levantine Sea & lonian Sea & Algero-Provencal Basin \\
\hline Average similarity (\%) & 57 & 63 & 56 & 42 \\
\hline Flabellia petiolata & - & - & - & - \\
\hline Mesophyllum alternans & 7 & 16 & - & - \\
\hline Mesophyllum expansum & - & 24 & - & - \\
\hline Peyssonnelia dubyi & 19 & - & - & - \\
\hline Peyssonnelia heteromorpha & - & 13 & - & - \\
\hline Peyssonnelia squamaria & 25 & 15 & 18 & 21 \\
\hline Peyssonnelia spp. & - & - & 9 & - \\
\hline Rhodophyta (spp.) & - & - & 11 & - \\
\hline Agelas oroides & 10 & - & - & 16 \\
\hline Porifera (spp.) & - & - & 13 & - \\
\hline Spirastrella cunctatrix & 11 & - & - & 13 \\
\hline Paramuricea clavata & - & - & - \\
\hline
\end{tabular}

Coralligenous assemblages were reported to have been invaded by alien species, such as Caulerpa spp. and Womersleyella setacea (Piazzi et al., 2007). Caulerpa cylindracea has been found to cover almost $60 \%$ of coralligenous habitats along the coast of Livorno (Piazzi \& Balata, 2009). In our case, Caulerpa cylindracea was only found at one station (TC1 in the Aegean Sea), with a low coverage (3\%). Although absent in the present study, the red turf alga Womersleyella setacea can form a dense carpet over encrusting corallines, thus inhibiting their photosynthetic activities and growth (Cebrian \& Rodríguez-Prieto, 2012).

Four distinct epibenthic coralligenous assemblages were identified in the present study, based on coverage of the main builders and constituents (coralline algae, sponges, and cnidarians). The eastern Mediterranean assemblages lacked gorgonians, whereas the average coverage of Paramuricea clavata reached $28 \%$ in the western Mediterranean. The eastern Mediterranean assemblages were largely composed of encrusting coralline algae and sponges, in agreement with the findings published by Sini (2015) and Sini et al. (2014). The eastern Mediterranean assemblages (Aegean and Levantine Seas) were somewhat similar to that (i.e. an assemblage characterized by massive sponges, non-calcareous encrusting algae [Peyssonnelia spp.] and ascidians) reported from the Adriatic Sea by Falace et al. (2015), although ANOSIM tests clearly demonstrate their biotic multivariate patterns are different. The results of this first large-scale Mediterranean approach demonstrated that coralligenous assemblages present a clear biotic gradient across the ecoregions considered, which can be detected when using species composition information patterns: the multivariate biotic patterns 


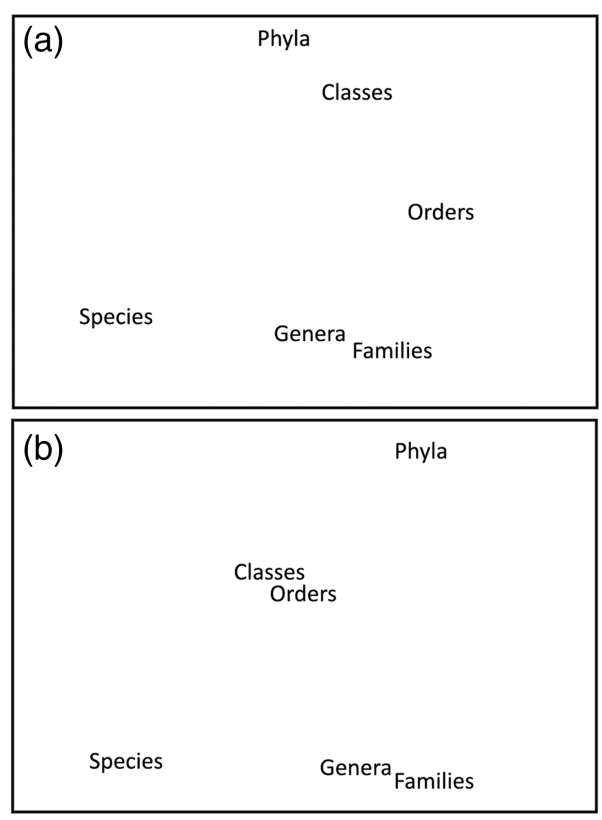

FIGURE 7 Second-stage multidimensional scaling plots, comparing inter-matrix relations between patterns from multiple taxonomic levels and at various geographical scales. (A) Image sample (stress $=0$ ); (B) stations in ecoregions (stress $=0$ )

of the locations within each of the ecoregions are more similar to each other than to those from the other ecoregions. This is in good agreement with the first hypothesis regarding the biotic gradient concept (Arvanitidis et al., 2002; Bellan-Santini, 1985; Fredj \& Laubier, 1985; Pérès, 1967; Surugiu et al., 2010).

The biotic multivariate pattern remains stable as the information is aggregated from species to higher taxonomic levels. Groups of samples that correspond to the different Mediterranean ecoregions are significantly different from each other at all taxonomic levels from the species to phylum. These findings confirm the second hypothesis on the taxonomic sufficiency concept, that is the assemblage pattern does not change significantly when the information is aggregated to higher taxonomic levels. Also, the comparison of the patterns deriving from the different taxonomic levels, as depicted in the second-stage non-metric MDS plots, shows the pattern coming from the species level to be most closely similar to those from genera and families. These results are in agreement with those from the previous studies focusing on the taxonomic sufficiency concept but in soft-bottom habitats (Ferraro \& Cole, 1995; Kingston \& Riddle, 1989; Warwick, 1988). For an adequate assessment of the spatial structure of the coralligenous assemblage it is sufficient to identify the taxa at the family level since their patterns are $>70 \%$ similar to those of genera and species. This similarity of the multivariate patterns decreases slightly to $>60 \%$ at the phylum level, but that is still acceptable as a surrogate taxonomic level to focus on in an assessment study, especially in areas for which baseline studies exist.

Based on these results, a biogeographic gradient along the Mediterranean ecoregions (Giakoumi et al., 2013; Notarbartolo di Sciara \& Agardy, 2010; Spalding et al., 2007) is revealed. Thus, our findings suggest a major longitudinal gradient of coralligenous assemblages, which is characterized by low percentages of common dominant species across the ecoregions. This large-scale spatial diversification of assemblage structure may be the result of geographical, historical (evolutionary), and/or environmental forcing (Gaston, Chown, \& Evans, 2008).

The above results further support our argument from the taxonomic sufficiency hypothesis, in that a cost-benefit-balanced monitoring of the coralligenous habitat can be accomplished at least at local and ecoregional spatial scales by using much less biological information, scientific expertise and resources. As patterns of the coralligenous communities used for monitoring remain much the same when the information is aggregated from the species to family level, it follows that trained technicians, para-taxonomists, students, or, in some cases, even trained citizen scientists may undertake the classification of the individuals on the photo-quadrats into families. This process can be achieved in a more industrial, faster, and cheaper way rather than the classification of the individuals into species by professional taxonomists. Hence, cost-effective conservation initiatives may be designed and implemented while citizen science networks may also contribute towards this end through data gathering and reporting to scientists and managers (Gatti et al., 2016; Gerovasileiou et al., 2016).

\section{5 | CONCLUSIONS}

The present study provides sound evidence on the utility of a standardized non-destructive photo-sampling protocol, developed in the framework of the CIGESMED project, in order to adequately study the coralligenous assemblages of the Mediterranean and test basic scientific concepts: biotic gradients and taxonomic sufficiency.

Sound data and information on the assemblage patterns have been created in the course of this project, which will serve as a body of evidence against which the results of future monitoring and conservation actions can be compared.

Surrogate taxonomic categories, higher than species such as genus and family, can be used to assess the multivariate pattern of the coralligenous assemblages. Even at the level of the phylum, little of the pattern structure is lost, which saves considerable time, effort, and investment during the assessment and monitoring of any conservation action on the coralligenous assemblages.

\section{ACKNOWLEDGEMENTS}

This study was carried out in the framework of CIGESMED project and was supported by: FRANCE - CNRS - ANR (Centre National de la Recherche Scientifique - Agence Nationale pour la Recherche) convention $\mathrm{n}^{\circ}$ 12-SEAS-0001-01/LIGAMEN - ANR convention $\mathrm{n}^{\circ}$ 12-SEAS-0001-02/IFREMER - ANR convention n'12-SEAS0001-03; GREECE - GSRT (General Secretariat for Research and Technology) 12SEAS-2-C2; TURKEY - TUBITAK (Türkiye Bilimsel ve Teknolojik Araştırma Kurumu) project number: 112Y393. The authors have no conflicts of interest to declare. 


\section{ORCID}

Melih Ertan Çinar https://orcid.org/0000-0002-1802-2801

Jean-Pierre Féral https://orcid.org/0000-0001-7627-0160

Christos Arvanitidis https://orcid.org/0000-0002-6924-5255

Romain David https://orcid.org/0000-0003-4073-7456

ErgünTas,kin https://orcid.org/0000-0003-0531-4546

Maria Sini https://orcid.org/0000-0002-9608-3503

Thanos Dailianis https://orcid.org/0000-0002-4102-9331

Alper Dogan https://orcid.org/0000-0002-4871-4059

Vasilis Gerovasileiou https://orcid.org/0000-0002-9143-7480

Alper Evcen https://orcid.org/0000-0003-1134-2551

Anne Chenuil https://orcid.org/0000-0001-8141-7147

Ertan Dagli https://orcid.org/0000-0001-6579-505X

Veysel Aysel https://orcid.org/0000-0003-3668-7046

Yannis Issaris https://orcid.org/0000-0002-8906-4099

Kerem Bakir https://orcid.org/0000-0002-3739-8396

Melina Nalmpantı https://orcid.org/0000-0002-4125-1389

Stephane Sartoretto https://orcid.org/0000-0001-7152-6075

Maria Salomidi https://orcid.org/0000-0002-7514-3562

Anastasia Sapouna https://orcid.org/0000-0002-9125-7359

Sermin Açik https://orcid.org/0000-0001-6456-2377

Charalampos Dimitriadis https://orcid.org/0000-0002-8381-4362

Drosos Koutsoubas https://orcid.org/0000-0002-9514-1644

Tuncer Katagan https://orcid.org/0000-0002-8914-7804

Bilal Öztürk https://orcid.org/0000-0002-5638-2496

Ferah Koçak https://orcid.org/0000-0002-3817-612X

Deniz Erdogan-Dereli https://orcid.org/0000-0003-2754-8378

Senem Önen https://orcid.org/0000-0003-1749-2673

Özge Özgen https://orcid.org/0000-0001-8228-4817

Neslihan Türkçü https://orcid.org/0000-0003-4440-5600

Fevzi Kirkim https://orcid.org/0000-0001-7279-8793

Mesut Önen https://orcid.org/0000-0001-5717-7104

\section{REFERENCES}

Airoldi, L. (2003). The effects of sedimentation on rocky coast assemblages. Oceanography and Marine Biology: An Annual Review, 41, 161-236.

Anderson, M. J., Gorley, R. N., \& Clarke, K. R. (2008). PERMANOVA+for PRIMER: Guide to software and statistical methods. PRIMER-E: Plymouth.

Antoniadou, C., Voultsiadou, E., \& Chintiroglou, C. (2006). Sublittoral megabenthos along cliffs of different profile (Aegean Sea, eastern Mediterranean). Belgian Journal of Zoology, 136, 69-79.

Arvanitidis, C., Bellan, G., Drakopoulos, P., Valavanis, V., Dounas, C., Koukouras, A., \& Eleftheriou, A. (2002). Seascape biodiversity patterns along the Mediterranean and the Black Sea: Lessons from the biogeography of benthic polychaetes. Marine Ecology Progress Series, 244, 139-152. https://doi.org/10.3354/meps244139

Arvanitidis, C., Somerfield, P. J., Chatzigeorgiou, G., Reizopoulou, S., Kevrekidis, T., \& Eleftheriou, A. (2009). Do multivariate analyses incorporating changes in pattern across taxonomic levels reveal anthropogenic stress in Mediterranean lagoons? Journal of Experimental Marine Biology and Ecology, 369, 100-109. https://doi.org/10.1016/j.jembe. 2008.10.032

Balata, D., Piazzi, L., Cecchi, E., \& Cinelli, F. (2005). Variability of Mediterranean coralligenous assemblages subject to local variation in sediment deposition. Marine Environmental Research, 60, 403-421. https://doi.org/10.1016/j.marenvres.2004.12.005
Ballesteros, E. (2006). Mediterranean coralligenous assemblages: A synthesis of present knowledge. Oceanography and Marine Biology: An Annual Review, 44, 123-195. https://doi.org/10.1201/ 9781420006391.ch4

Bellan-Santini, D. (1985). The Mediterranean benthos: Reflections and problems raised by a classification of the benthic assemblages. In Press: Moraitou-Apostolopoulou, M., \& Kiortsis V. (Eds.), Mediterranean marine ecosystems (pp. 19-48), Boston, Springer.

Bianchi, C. N., Pronzato, R., Cattaneo-Vietti, R., Benedetti-Cecchi, L., Morri, C., Pansini, M., ... Bavestrello, G. (2004). Mediterranean marine benthos: A manual of methods for its sampling and study. Hard bottoms. Biologia Marina Mediterranea, 11, 185-215.

Boudouresque, C. F., Blanfuné, A., Harmelin-Vivien, M., Personnic, S., Ruitton, S., Thibaut, T., \& Verlaque, M. (2016). Where Seaweed Forests Meet Animal Forests: The Examples of Macroalgae in Coral Reefs and the Mediterranean Coralligenous Ecosystem. In S. Rossi, L. Bramanti, A. Gori, \& C. Orejas Saco del Valle (Eds.), Marine animal forests, the ecology of benthic biodiversity hotspots (pp. 1-28), Switzerland, Springer Verlag.

Bracchi, V. A., Basso, D., Marchese, F., Corselli, C., \& Savini, A. (2017). Coralligenous morphotypes on subhorizontal substrata: A new categorization. Continental Shelf Research, 144, 10-20. https://doi.org/10.1016/ j.csr.2017.06.005

Bray, J. R., \& Curtis, J. T. (1957). An ordination of upland forest communities of southern Wisconsin. Ecological Monographs, 27, 325-349. https://doi.org/10.2307/1942268

Calcinai, B., Bertolino, M., Bavestrello, G., Montori, S., Mori, M., Pica, D., Valisano, L., \& Cerrano, C. (2015). Comparison between the sponge fauna living outside and inside the coralligenous bio construction: A quantitative approach. Mediterranean Marine Science, 16, 413-418. https://doi.org/10.12681/mms.900

Casellato, S., \& Stefanon, A. (2008). Coralligenous habitat in the northern Adriatic Sea: An overview. Marine Ecology, 29, 321-341. https://doi. org/10.1111/j.1439-0485.2008.00236.x

Casoli, E., Nicoletti, L., Mastrantonio, G., Jona-Lasinio, G., Belluscio, A., \& Ardizzone, G. D. (2017). Scuba diving damage on coralligenous builders: Bryozoan species as an indicator of stress. Ecological Indicators, 74, 441-450. https://doi.org/10.1016/j.ecolind. 2016.12.005

Cebrian, E., \& Rodríguez-Prieto, C. (2012). Marine Invasion in the Mediterranean Sea: The role of abiotic factors when there is no biological resistance. PLoS ONE, 7, e31135. https://doi.org/10.1371/ journal.pone.0031135

Cecchi, E., Gennaro, P., Piazzi, L., Ricevuto, E., \& Serena, F. (2014). Development of a new biotic index for ecological status assessment of Italian coastal waters based on coralligenous macroalgal assemblages. European Journal of Phycology, 49, 298-312. https://doi.org/10.1080/ 09670262.2014 .918657

Cerrano, C., Bavestrello, G., Bianchi, C. N., Cattaneo-Vietti, R., Bava, S., Morganti, C., ... Sponga, F. (2000). A catastrophic mass mortality episode of gorgonians and other organisms in the Ligurian Sea (NW Mediterranean), summer 1999. Ecological Letters, 3, 284-293. https://doi.org/10.1046/j.1461-0248.2000.00152.x

Cerrano, C., Danovaro, R., Gambi, C., Pusceddu, A., Riva, A., \& Schiaparelli, S. (2010). Gold coral (Savalia savaglia) and gorgonian forests enhance benthic biodiversity and ecosystem functioning in the mesophotic zone. Biodiversity and Conservation, 19, 153-167. https:// doi.org/10.1007/s10531-009-9712-5

Çinar, M. E., Gönülal, O., \& Öztürk, B. (2018). Wanted dead or alive: Corallium rubrum (Cnidaria: Anthozoa) on the coasts of Turkey. Cahiers de Biologie Marine, 59, 175-179. https://doi.org/10.21411/CBM.A. $1043 F 293$

Clarke, K. R. (1993). Non-parametric multivariate analyses of changes in community structure. Australian Journal of Ecology, 18, 117-143. https://doi.org/10.1111/j.1442-9993.1993.tb00438.x 
Clarke, K. R., \& Gorley, R. N. (2006). PRIMER v6: User manual/tutorial. Plymouth: PRIMER-E Ltd.

Clarke, K. R., Gorley, R. N., \& Warwick, R. M. (2014). Change in marine communities: An approach to statistical analysis and interpretation (3th ed.). Plymouth: PRIMER-E Ltd.

Clarke, K. R., \& Warwick, R. M. (2001). A further biodiversity index applicable to species lists: Variation in taxonomic distinctness. Marine Ecological Progress Series, 216, 265-278. https://doi.org/10.3354/ meps216265

Coma, R., Ribes, M., Serrano, E., Jiménez, E., Salat, J., \& Pascual, J. (2009). Global warming-enhanced stratification and mass mortality events in the Mediterranean. Proceedings of the National Academy of Sciences of the United Sates of America, 106, 6176-6181. https://doi.org/10. 1073/pnas.0805801106

David, R., Arvanitidis, C., Çinar, M. E., Sartoretto, S., Doğan, A., Dubois, S., ... Féral, J. P. (2015). CIGESMED protocols: How to implement a multidisciplinary approach on a large scale for coralligenous habitats surveys. In C. Bouafif, H. Langar, \& A. Ouerghi (Eds.), Proceedings of the 2nd Mediterranean symposium on the conservation of the coralligenous and other calcareous bio-concretions (pp. 66-71). Portorož, Tunis: RAC/SPA publication.

David, R., Dubois, S., Erga, Z., Guillemain, D., Thierry de Ville d'Avray, L., Arvanitidis, C., ... Féral, J. P. (2014). CIGESMED's protocol and network (Coralligenous based Indicators to evaluate and monitor the "Good Environmental Status" of Mediterranean coastal waters). In F. Benincasa (Ed.), Proceedings of the 5th international symposium monitoring of Mediterranean coastal areas: Problems and measurement techniques (pp. 828-843), Livorno, Italy.

Deter, J., Descamp, P., Ballesta, L., Boissery, P., \& Holon, F. (2012). A preliminary study toward an index based on coralligenous assemblages for the ecological status assessment of Mediterranean French coastal waters. Ecological Indicators, 20, 345-352. https://doi.org/10.1016/j. ecolind.2012.03.001

Falace, A., Kaleb, S., Curiel, D., Miotti, C., Galli, G., Querin, S., ... Bandelj, V. (2015). Calcareous bio-concretions in the northern Adriatic Sea: Habitat types, environmental factors that influence habitat distributions, and predictive modeling. PLoS ONE, 10, e0140931. https://doi.org/10. 1371/journal.pone.0140931

Féral, J. P., Fourt, M., Perez, T., Warwick, R. M., Emblow, C., Heip, C., ... Hummel, H. (2003). European marine biodiversity indicators. Yerseke: NIOO-CEME.

Ferdeghini, F., Acunto, S., Cocito, S., \& Cinelli, F. (2000). Variability at different spatial scales of a coralligenous assemblage at Giannutri Island (Tuscan Archipelago, northwest Mediterranean). Hydrobiologia, 440, 27-36. https://doi.org/10.1007/978-94-017-1982-7_3

Ferraro, S. P., \& Cole, F. A. (1995). Taxonomic level sufficient for assessing pollution impacts on the southern California bight macrobenthosrevisited. Environmental Toxicology and Chemistry, 1, 1031-1040. https://doi.org/10.1002/etc.5620140614

Ferrigno, F., Appolloni, L., Russo, G. F., \& Sandulli, R. (2018). Impact of fishing activities on different coralligenous assemblages of Gulf of Naples (Italy). Journal of the Marine Biological Association of the United Kingdom, 98, 41-50. https://doi.org/10.1017/s00253 15417001096

Fredj, G., \& Laubier, L. (1985). The Deep Mediterranean Benthos. In M. Moraitou-Apostolopoulou, \& V. Kiortsis (Eds.), Mediterranean marine ecosystems (pp. 109-145), Boston: Springer.

Garrabou, J., Sala, E., Arcas, A., \& Zabala, M. (1998). The impact of diving on rocky sublittoral communities: A case study of a bryozoan population. Conservation Biology, 12, 302-312. https://doi.org/10.1046/j. 1523-1739.1998.96417.x

Gaston, K. J., Chown, S. L., \& Evans, K. L. (2008). Ecogeographical rules: Elements of a synthesis. Journal of Biogeography, 35, 483-500. https://doi.org/10.1111/j.1365-2699.2007.01772.x
Gatti, G., Dimitriadis, C., Gerovasileiou, V., Dailianis, T., Panteri, E., Issaris, Y., ... Féral, J. P. (2016). Citizen Science for CIGESMED: Involving divers in Marine Biological Monitoring. In Press: 51st European Marine Biology Symposium (pp. 39), Rhodes, Greece.

Gatti, G., Montefalcone, M., Rovere, A., Parravicini, V., Morri, C., Albertelli, G., \& Bianchi, C. N. (2012). Seafloor integrity down the harbor waterfront: The coralligenous shoals off Vado Ligure (NW Mediterranean). Advances in Oceanography and Limnology, 3, 51-67. https://doi.org/10.1080/19475721.2012.671190

Gerovasileiou, V., Dailianis, T., Panteri, E., Michalakis, N., Gatti, G., Sini, M., ... Arvanitidis, C. (2016). CIGESMED for divers: Establishing a citizen science initiative for the mapping and monitoring of coralligenous assemblages in the Mediterranean Sea. Biodiversity Data Journal, 4, e8692. https://doi.org/10.3897/bdj.4.e8692

Gerovasileiou, V., Sini, M., Poursanidis, D., \& Koutsoubas, D. (2009). Contribution to the knowledge of coralligenous communities in the NE Aegean Sea. In C. Pergent-Martini, \& M. Brichet (Eds.), Proceedings of the 1st Mediterranean symposium on the conservation of the coralligenous and other calcareous bio-concretions (pp. 204-207), Tabarka, Tunis: RAC/SPA publication.

Gerovasileiou, V., \& Voultsiadou, E. (2012). Marine caves of the Mediterranean Sea: A sponge biodiversity reservoir within a biodiversity hotspot. PLoS ONE, 7, e39873. https://doi.org/10.1371/journal.pone. 0039873

Giakoumi, S., Sini, M., Gerovasileiou, V., Mazor, T., Beher, J., Possingham, H. P., ... Katsanevakis, S. (2013). Ecoregion-based conservation planning in the Mediterranean: Dealing with large-scale heterogeneity. PLoS ONE, 8, e76449. https://doi.org/10.1371/journal.pone. 0076449

Gili, J. M., \& Ballesteros, E. (1991). Structure of cnidarian populations in Mediterranean sublittoral benthic communities as a result of adaptation to different environmental conditions. Oecologia Aquatica, 10, 243-254.

Hong, J. S. (1982). Contribution à l'étude des peuplements d'un fond coralligène dans la région Marseillaise en Méditerranée NordOccidentale. Bulletin of Korea Ocean Research and Development Institute, 4, 27-51.

Hong, J. S. (1983). Environmental impact of the pollution on the benthic coralligenous community in the Gulf of Fos, northwestern Mediterranean. Bulletin of Korean Fisheries Society, 16, 273-290.

Kingston, P. F., \& Riddle, M. J. (1989). Cost effectiveness of benthic faunal monitoring. Marine Pollution Bulletin, 20, 490-496. https://doi.org/10. 1016/0025-326x(89)90135-5

Kruskal, J. B., \& Wish, M. (1978). Multidimensional scaling. Beverly Hills: Sage Publications.

Laubier, L. (1966). Le coralligène des Albères: Monographie biocénotique. Annales de l'Institut Océanographique de Monaco, 43, 139-316.

Linares, C., Zabala, M., Garrabou, J., Coma, R., Diaz, D., Hereu, B., \& Dantart, L. (2010). Assessing the impact of diving in coralligenous communities: The usefulness of demographic studies of red gorgonian populations. Scientific Report of Port-Cros National Park, 24, 161-184.

Longo, C., Cardone, F., Pierri, C., Mercurio, M., Mucciolo, S., Marzano Nonnis, C., \& Corriero, G. (2018). Sponges associated with coralligenous formations along the Apulian coasts. Marine Biodiversity, 48, 2151-2163. https://doi.org/10.1007/s12526-017-0744-x

Martin, C. S., Giannoulaki, M., De Leo, F., Scardi, M., Salomidi, M., Knitweiss, L., ... Fraschetti, S. (2014). Coralligenous and maërl habitats: Predictive modelling to identify their spatial distributions across the Mediterranean Sea. Scientific Reports, 4, 5073. https://doi.org/10. 1038/srep05073

Martin, S., \& Gattuso, J. P. (2009). Response of Mediterranean coralline algae to ocean acidification and elevated temperature. Global Change Biology, 15, 2089-2100. https://doi.org/10.1111/j.1365-2486.2009. 01874.x 
Notarbartolo di Sciara, G., \& Agardy, T. (2010). Overview of scientific findings and criteria relevant to identifying SPAMIs in the Mediterranean open seas, including the deep sea. Tunis: UNEP-MAP.

Olsgard, F., \& Somerfield, P. J. (2000). Surrogates in marine benthic investigations - which taxonomic unit to target? Journal of Aquatic Ecosystem and Stress Recovery, 7, 25-42. https://doi.org/10.1023/A: 1009967313147

Olsgard, F., Somerfield, P. J., \& Carr, M. R. (1998). Relationships between taxonomic resolution, macrobenthic community patterns and disturbance. Marine Ecological Progress Series, 172, 25-36. https://doi.org/ 10.3354/meps172025

Pearson, T. H., \& Rosenberg, R. (1978). Macrobenthic succession in relation to organic enrichment and pollution of the marine environment. Oceanography and Marine Biology: An Annual Review, 16, 229-311.

Pérès, J. M. (1967). The Mediterranean benthos. Oceanography and Marine Biology: An Annual Review, 5, 449-533.

Pérès, J. M., \& Picard, J. (1958). Recherches sur les peuplements benthiques de la Méditerranée nord-orientale. Annales de l'Institut Océanographique de Monaco, 34, 213-291.

Piazzi, L., \& Balata, D. (2009). Invasion of alien macroalgae in different Mediterranean habitats. Biological Invasions, 11, 193-204. https://doi. org/10.1007/s10530-008-9224-3

Piazzi, L., Balata, D., \& Cinelli, F. (2007). Invasions of alien macroalgae in Mediterranean coralligenous assemblages. Cryptogamie Algologie, 28, 289-301.

Piazzi, L., Gennaro, P., Montefalcone, M., Bianchi, C. N., Cecchi, E., Morri, C., \& Serena, F. (2019). STAR: An integrated and standardized procedure to evaluate the ecological status of coralligenous reefs. Aquatic Conservation: Marine and Freshwater Ecosystems, 29, 189-201. https://doi.org/10.1002/aqc.2983

Ponti, M., Perlini, R. A., Ventra, V., Grech, D., Abbiati, M., \& Cerrano, C. (2014). Ecological shifts in Mediterranean coralligenous assemblages related to gorgonian forest loss. PLoS ONE, 9, e102782. https://doi. org/10.1371/journal.pone.0102782

RAC/SPA-UNEP/MAP. (2014). Monitoring protocol for reefs - Coralligenous community. Tunis: RAC/SPA - MedMPAnet Project. 35pp

Sala, E., Ballesteros, E., Dendrinos, P., Di Franco, A., Ferretti, F., Foley, D., ... Zabala, Z. (2012). The Structure of Mediterranean rocky reef rcosystems across environmental and human gradients, and conservation implications. PLoS ONE, 7, e32742. https://doi.org/10.1371/ journal.pone.0032742

Salomidi, M., Smith, C., Katsanevakis, S., Panayotidis, P., \& Papathanassiou, V. (2009). Some observations on the structure and distribution of gorgonian assemblages in the eastern Mediterranean Sea. In C. Pergent-Martini, \& M. Brichet (Eds.), Proceedings of the 1st Mediterranean symposium on the conservation of the coralligenous and other calcareous bio-concretions (pp. 242-245), Tabarka, Tunis: RAC/SPA publication.

Sartoretto, S., Schohn, T., Bianchi, C. N., Morri, C., Garrabou, J., Ballesteros, E., ... Gatti, G. (2017). An integrated method to evaluate and monitor the conservation state of coralligenous habitats: The INDEX-COR approach. Marine Pollution Bulletin, 120, 222-231. https://doi.org/10.1016/j.marpolbul.2017.05.020

Sini, M. (2015). Ecology and diversity of coralligenous assemblages in the Aegean Sea (PhD thesis). Department of Marine Sciences, University of the Aegean, Greece.

Sini, M., Garrabou, J., \& Koutsoubas, D. (2014). Diversity and structure of coralligenous assemblages dominated by Eunicella cavolini (Koch, 1887) in the Aegean Sea. In C. Bouafif, H. Langar, \& A. Ouerghi (Eds.), 2nd Mediterranean symposium on the conservation of coralligenous and other calcareous bio-concretions (pp.247), Portorož, Slovenia: RAC/SPA publication.

Sini, M., Kipson, S., Linares, C., Koutsoubas, D., \& Garrabou, J. (2015). The yellow gorgonian Eunicella cavolini: Demography and disturbance levels across the Mediterranean Sea. PLoS ONE, 10, e0126253. https://doi.org/10.1371/journal.pone.0126253

Somerfield, P. J., \& Clarke, K. R. (1995). Taxonomic levels, in marine community studies, revisited. Marine Ecology Progress Series, 127, 113-119. https://doi.org/10.3354/meps127113

Spalding, M. D., Fox, H. E., Allen, G. R., Davidson, N., Ferdaña, Z. A., Finlayson, M., ... Robertson, J. (2007). Marine ecoregions of the world: A bioregionalization of coastal and shelf areas. Bioscience, 57, 573-583. https://doi.org/10.1641/b570707

Surugiu, V., Revkov, N., Todorova, V., Papageorgiou, N., Valavanis, V., \& Arvanitidis, C. (2010). Spatial patterns of biodiversity in the Black Sea: An assessment using benthic polychaetes. Estuarine, Coastal and Shelf Science, 88, 165-174. https://doi.org/10.1016/j.ecss.2010.03.012

Thierry De Ville D'Avray, L. (2018). Identification and valuation of ecosystem services provided by coralligenous habitats ( $\mathrm{PhD}$ thesis). Institut Méditerranéen de Biodiversité et d'Ecologie Marine et Continentale (IMBE), France.

Torgerson, W. S. (1958). Theory and methods of scaling. New York: Wiley.

True, M. A. (1970). Étude quantitative de quatre peuplements sciaphiles sur substrat rocheaux dans la région marseilleise. Bulletin de l'Institut océanographique de Monaco, 69, 1-48.

Trygonis, V., \& Sini, M. (2012). photoQuad: A dedicated seabed image processing software, and a comparative error analysis of four photoquadrat methods. Journal of Experimental Marine Biology and Ecology, 425, 99-108. https://doi.org/10.1016/j.jembe.2012.04.018

UNEP. (1998). Revised criteria for the evaluation of the conservation interest of Mediterranean Marine Habitat Types and proposed rating. Annex IV. UNEP (OCA)/MED WG. 149/5.

UNEP/MAP/SPA. (2018). SAP/RAC: SPA-BD protocol - annex II: List of endangered or threatened species. Tunisia, $10 \mathrm{pp}$.

Vanderklift, M. A., Ward, T. J., \& Jacoby, C. A. (1996). Effect of reducing taxonomic resolution on ordinations to detect pollution-induced gradients in macrobenthic infaunal assemblages. Marine Ecological Progress Series, 136, 137-145. https://doi.org/10.3354/meps136137

Warwick, R. M. (1988). The level of taxonomic discrimination required to detect pollution effects on marine benthic communities. Marine Pollution Bulletin, 19, 259-268. https://doi.org/10.1016/0025-326x(88) 90596-6

Warwick, R. M., \& Clarke, K. R. (1998). Taxonomic distinctness and environmental assessment. Journal of Applied Ecology, 35, 532-543. https://doi.org/10.1046/j.1365-2664.1998.3540532.x

Warwick, R. M., \& Light, J. (2001). Death assemblages of molluscs on St. Martin's flats, Isles of Scilly: A surrogate for regional biodiversity? Biodiversity and Conservation, 11, 99-112.

Warwick, R. M., Platt, H. M., Clarke, K. R., Agard, J., \& Gobin, J. (1990). Analysis of macrobenthic and meiobenthic community structure in relation to pollution and disturbance in Hamilton Harbour, Bermuda. Journal of Experimental Marine Biology and Ecology, 138, 119-142.

\section{SUPPORTING INFORMATION}

Additional supporting information may be found online in the Supporting Information section at the end of this article.

\section{Funding information}

CNRS - ANR, Grant/Award Numbers:

12-SEAS-0001-01, 12-SEAS-0001-02,

12-SEAS-0001-03; General Secretariat for Research and Technology, Grant/

Award Number: 12SEAS-2-C2; Türkiye Bilimsel ve Teknolojik Aras, tirma

Kurumu, Grant/Award Number: 112 Y393 